\title{
An Update on Development of Small-Molecule Plasmodial Kinase Inhibitors
}

\author{
Chantalle Moolman ${ }^{1}\left(\mathbb{D}\right.$, Rencia van der Sluis ${ }^{2} \mathbb{D}$, Richard M. Beteck ${ }^{1}$ and Lesetja J. Legoabe ${ }^{1, *(\mathbb{D})}$ \\ 1 Centre of Excellence for Pharmaceutical Sciences, North-West University, Private Bag X6001, \\ Potchefstroom 2520, South Africa; 21204756@nwu.ac.za (C.M.); 25159194@nwu.ac.za (R.M.B.) \\ 2 Focus Area for Human Metabolomics, Biochemistry, North-West University, Private Bag X6001, \\ Potchefstroom 2520, South Africa; 21224919@nwu.ac.za \\ * Correspondence: lesetja.legoabe@nwu.ac.za; Tel.: +27-018-299-2182
}

Received: 29 September 2020; Accepted: 29 October 2020; Published: 7 November 2020

check for updates

\begin{abstract}
Malaria control relies heavily on the small number of existing antimalarial drugs. However, recurring antimalarial drug resistance necessitates the continual generation of new antimalarial drugs with novel modes of action. In order to shift the focus from only controlling this disease towards elimination and eradication, next-generation antimalarial agents need to address the gaps in the malaria drug arsenal. This includes developing drugs for chemoprotection, treating severe malaria and blocking transmission. Plasmodial kinases are promising targets for next-generation antimalarial drug development as they mediate critical cellular processes and some are active across multiple stages of the parasite's life cycle. This review gives an update on the progress made thus far with regards to plasmodial kinase small-molecule inhibitor development.
\end{abstract}

Keywords: malaria; Plasmodium; kinases; kinase inhibitors; antimalarial agents

\section{Introduction}

Although significant progress has been made with regards to worldwide malaria control and eradication, this infectious disease continues to have devastating effects, especially in developing countries. An estimated 228 million malaria cases and 405,000 malaria-related deaths were reported globally in 2018 [1]. The ongoing coronavirus (COVID-19) pandemic could also have a profound negative impact on the progress made thus far in the fight against malaria [2]. Patients presenting with fever or requiring malaria treatment are now less likely to visit health care facilities out of fear of contracting COVID-19 [3]. Lockdown periods have disrupted the supply of malaria rapid diagnostic tests, antimalarial drugs and other interventions [3]. A number of antimalarial drugs (e.g., artemisinin, chloroquine and hydroxychloroquine) have also been repurposed for COVID-19 treatment, despite a lack of scientific evidence and approval [3]. This has resulted in a shortage of these drugs and, in the long-run, an increased risk of drug resistance due to improper use of antimalarial monotherapies [3].

Apart from the potential impact of the pandemic, recurring antimalarial drug resistance poses a major threat to malaria control and elimination. P. falciparum, the Plasmodium species responsible for the majority of malaria-related deaths, is resistant to most antimalarial drugs, including the current first-line artemisinin-based combination therapies [1,4]. The second most common human malaria species, P. vivax, has developed widespread resistance to chloroquine [5]. Malaria parasites can also develop cross-resistance to antimalarial drugs from the same chemical class or with the same mode of action, which further exacerbates the problem [6].

The life cycle of the malaria parasite is complex; it consists of an asexual stage which occurs in the human host and a sexual stage which occurs in the mosquito vector [7]. Existing antimalarial drugs are highly stage-specific, with the majority targeting blood-stage parasites for treatment of 
symptomatic malaria [7]. In order to eliminate and eventually eradicate malaria, the focus needs to shift from mainly providing curative treatment to blocking disease transmission [8]. Achieving this goal requires a new generation of cost-effective antimalarial agents that are safe and well-tolerated in a wide range of recipients, including vulnerable populations such as pregnant women and infants [8]. Since drug development is expensive and can take up to 15 years before reaching the market, it is important to have clear guidelines [8]. The Medicines for Malaria Venture (MMV) published defined criteria for the types of individual molecules (target candidate profiles (TCPs)) and drug formulations (target product profiles (TPP)) that would be ideal for new malaria therapy [8]. TPP-1 focusses on treating malaria infections and includes a combination of molecules with blood-stage activity (TCP-1), transmission-blocking activity (TCP-5) and activity against relapse causing liver stages (TCP-3) [8]. Alternatively, TPP-1 could also consist of rapid-acting TCP-1 molecules when treating severe/complicated malaria [8]. TPP-2 focusses on chemoprevention of travelers to endemic regions or during epidemics and includes molecules with TCP-1 and hepatic schizont activity (TCP-4) [8].

Plasmodial kinases have been explored as targets for next-generation antimalarial agents due to their involvement in various critical cellular processes throughout the life cycle of the parasite [9-11]. The P. falciparum kinome is predicted to encode 85 to 99 protein kinase genes [12,13] as well as a small number of lipid kinase genes. Overall, the P. falciparum kinome displays significant divergence from the eukaryotic kinome. The 65 plasmodial kinases that cluster within established eukaryotic protein kinase (ePK) groups (CAMK, AGC, CMGC, CK1 and TKL groups) often display structural and functional characteristics that are not seen in their mammalian counterparts $[9,13]$. The plasmodial kinome also contains protein kinases that have no mammalian orthologues (orphan kinases) or display homology with more than one of the established ePK groups (composite or hybrid kinases) [9]. These differences can be exploited for selective antimalarial drug development.

Progress on plasmodial kinase inhibitor development up until the beginning of 2018 was discussed in a detailed review by Cabrera and co-workers [14]. Herein, we give an overview thereof, as well as discussing additional kinases and new research related to plasmodial kinase inhibitor development.

\section{Calcium-Dependent Protein Kinases (CDPKs)}

Enzymes from the classical $\mathrm{Ca}^{2+} / \mathrm{calmodulin-dependent} \mathrm{protein} \mathrm{kinase} \mathrm{(CaMK)} \mathrm{group} \mathrm{seem} \mathrm{to}$ be rare in the P. falciparum kinome [15]. However, the kinome contains calcium-dependent protein kinases (CDPKs) which have a C-terminal calmodulin-like domain that is highly homologous to the CaMK group [16]. CDPKs comprise a unique family of serine/threonine kinases only found in plants, protozoans (including apicomplexan parasites) and some algae [17]. These enzymes play an important role in calcium signalling during the various life stages of the Plasmodium parasite [15]. Seven members of the CDPK family (PfCDPK1 to PfCDPK7) have been identified in P. falciparum [16]. PfCDPK1 is expressed at all stages of the Plasmodium parasite life cycle. During asexual parasite development, PfCDPK1 plays a role in parasite motility $[18,19]$, microneme secretion and subsequent erythrocyte invasion [20], as well as merozoite egress from mature schizonts [19]. Previous studies have shown that PfCDPK1 is likely to be essential for asexual development $[19,21,22]$; however, the parasite might have other mechanisms in place to compensate for loss of $P f C D P K 1$ activity $[21,23,24]$. During the sexual development of the parasite, $P f C D P K 1$ activity is indispensable for gametogenesis and subsequent infection of the mosquito vector [21]. In addition, the P. berghei homologue (PbCDPK1) is also involved in ookinete development [25].

$P f C D P K 2, P f C D P K 3$ and $P f C D P K 4$ are all predominantly expressed during the sexual stage of the parasite development [26-28]. PfCDPK2 and PfCDPK4 are essential for male gametocyte exflagellation and transmission to the mosquito vector [26,27]. In addition, PfCDPK4 is also required for sporozoite invasion of hepatocytes [29]. Although the exact function of PfCDPK3 is not yet known, its P. berghei orthologue $(\mathrm{PbCDPK} 3)$ is expressed in ookinetes where it regulates motility required for invading the midgut of the mosquito $[30,31]$. 
$P f C D P K 5$ and $P f C D P K 7$ are expressed during the asexual erythrocytic stage. PfCDPK5 acts synergistically with P. falciparum protein kinase G (PfPKG) to regulate microneme secretion which is required for merozoites to egress mature schizonts [32,33]. Although PfCDPK5 is essential, the parasite is able to compensate for loss of PfCDPK5 activity through hyperactivation of PfPKG [32]. While CDPK7 is not essential to parasite viability, it still plays an important role in the development of the erythrocytic parasite. The growth rate of CDPK7 knockout parasites is significantly reduced due to a delay in maturation of ring-stage parasites to trophozoites and the release of fewer merozoites from each schizont [34]. Little is currently known about CDPK6 of P. falciparum. The P. berghei orthologue ( $P b C D P K 6)$ signals to sporozoites when to stop migration and initiate invasion of hepatocytes [35].

\subsection{Inhibitor Development for the CDPK Group}

The CDPKs are promising drug targets for the development of new antiplasmodial agents as there are no CDPK orthologues in the human host [16]. A unique structural feature of many parasitic CDPKs is the small gatekeeper residue at the hinge region [36]. A small gatekeeper residue results in enlargement of the hydrophobic pocket that accommodates the ATP purine group in the ATP-binding site [36]. Various medicinal chemistry campaigns have developed small-molecule inhibitors termed bumped kinase inhibitors (BKIs) that contain a bulky C3-aryl substituent that can occupy this enlarged hydrophobic pocket [36]. Most mammalian kinases have larger gatekeeper residues that block access to the bulky substituent of BKIs, therefore allowing better selectivity towards the parasitic kinases [36]. Amongst $P$. falciparum CDPKs, PfCDPK4 has the smallest gatekeeper, which is a serine residue, followed by $P f C D P K 1$ with a medium threonine gatekeeper residue [37]. PfCDPK2 (methionine), PfCDPK3 (methionine) and PfCDPK5 (leucine) all have bulky gatekeeper residues [37]. P. falciparum CDPK inhibitor development has mainly focussed on PfCDPK1 and PfCDPK4, and most of these inhibitors are BKIs [14].

\subsection{1. $P f C D P K 1$}

High-throughput screening campaigns have identified various scaffolds as PfCDPK1 inhibitors (Figure 1), including 2,3,9-trisubstituted purines (1) [19], indolizines (2) [38] and imidazopyridazines (3-5) [23,38-42]. Of all these scaffolds, imidazopyridazines have been studied more intently.<smiles>N[C@H]1CC[C@H](Nc2nc(Nc3ccc(C(=O)N4CCCCC4)cc3)c3ncn(-c4cccc(F)c4)c3n2)CC1</smiles>

1

PfCDPK1 IC50: $17 \mathrm{nM}$

Pf3D7 blood stage EC50: $230 \mathrm{nM}$<smiles>Cc1ccc(C(=O)c2c(N)c(C(N)=O)c3ccccn23)cc1</smiles>

2

PfCDPK1 Ki: 262 nM

Figure 1. Cont. 


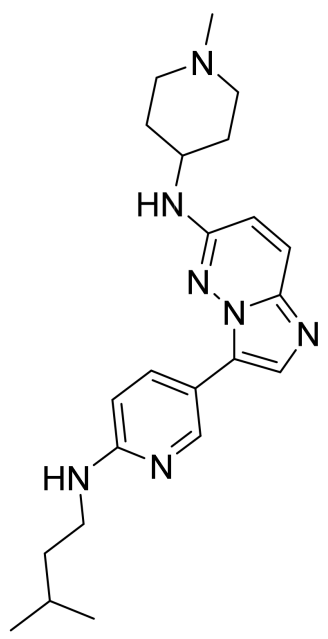

3

PfCDPK1 IC 50

Pf3D7 blood stage EC 50

In vivo $P b$ mouse model

(\% parasitemia

reduction, oral dose)

Once daily, 4 days<smiles>N[C@H]1CC[C@H](Nc2ccc3ncc(-c4cn[nH]c4)n3n2)CC1</smiles>

4

$70 \mathrm{nM}$

$103 \mathrm{nM}$

ND<smiles>CN1CCC(Nc2ccc3ncc(-c4ccc(Nc5ncc(Cl)cc5F)cc4)n3n2)CC1</smiles>

5

$12 \mathrm{nM}$

$80 \mathrm{nM}$

$51 \%$

$50 \mathrm{mg} / \mathrm{kg}$

Once daily, 4 days

Figure 1. The different scaffolds identified as inhibitors of PfCDPK1. IC ${ }_{50}$ : half-maximal inhibitory concentration; Pf3D7: Plasmodium falciparum 3D7 strain; EC $_{50}$ : half-maximal effective concentration; $\mathrm{K}_{\mathrm{i}}$ : inhibitory constant; Pb: Plasmodium berghei; ND: not determined.

Imidazopyridazines are generally potent $P f C D P K 1$ inhibitors, with some compounds demonstrating low micromolar to submicromolar activity against recombinant PfCDPK1 and P. falciparum erythrocytic parasites [23,38-42]. However, discrepancies between the enzymatic and whole-cell activities are generally reported for these compounds, which may be due to off-target activity or permeability issues [38,39]. Considerable effort was made to improve the selectivity and ADME (absorption, distribution, metabolism, excretion) profiles of imidazopyridazines, which resulted in compounds with well-balanced PfCDPK1 potency, permeability and in vitro activity against $P$. falciparum erythrocytic stage parasites [40-42]. Despite these efforts, studies still reported only modest in vivo activity in a P. berghei mouse model [39-41]. Further exploration of the mechanism of action of imidazopyridazines demonstrated that these compounds could be grouped into two classes based on the type of aromatic linker between the core and the R2 substituent (Figure 2) [23]. Class 1 compounds (6) had a pyrimidine linker and inhibited P. falciparum parasite growth at the late schizont stage, while class 2 compounds (7) had a non-pyrimidine linker and inhibited the trophozoite stage of P. falciparum. Two additional parasitic targets were also identified for imidazopyridazines: class 1 compounds inhibited PfPKG and class 2 compounds inhibited PfHSP90 (a chaperone protein of $P$. falciparum). These results suggest that the activity of imidazopyridazines against erythrocytic P. falciparum parasites is primarily due to inhibition of $P f \mathrm{PKG}$ and $P f \mathrm{HSP} 90$, rather than PfCDPK1 inhibition. 


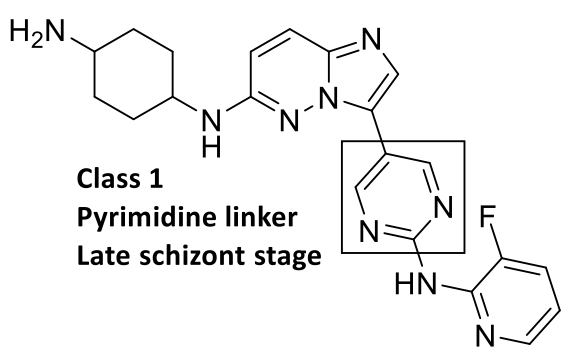

6

PfCDPK1 IC 50

PfPKG IC50

PfHSP90 KD

Pf3D7 blood stage EC50

$$
\begin{gathered}
0.008 \mu \mathrm{M} \\
0.002 \mu \mathrm{M} \\
\mathrm{ND}
\end{gathered}
$$$$
0.034 \mu \mathrm{M}
$$

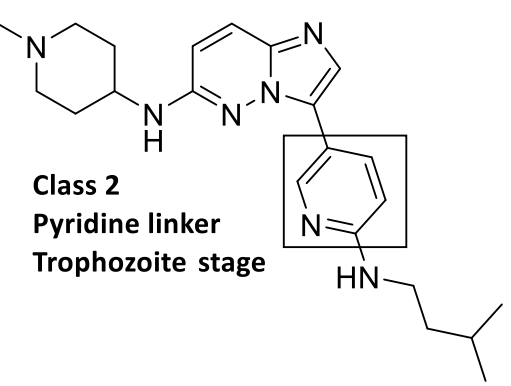

7

$0.074 \mu \mathrm{M}$

$>1 \mu \mathrm{M}$

$6.170 \mu \mathrm{M}$

$0.215 \mu \mathrm{M}$

Figure 2. Class 1 and 2 imidazopyridazine-based $P f C D P K 1$ inhibitors. $\mathrm{K}_{\mathrm{D}}$ : equilibrium dissociation constant. ND: not determined.

More recently, Flaherty and co-workers [43] designed a hydrocarbon constrained peptide that mimics the C-terminal helical region of the PfCDPK1 junction domain (J-domain). The autoinhibitory J-domain is located between the catalytic domain and the calmodulin-like domain and blocks the active site by acting as a pseudosubstrate when the kinase is in its inactive state. By mimicking the activity of the J-domain, the constrained peptide inhibits PfCDPK1 by locking the kinase in its inactive state. Uptake of the constrained peptide by P. falciparum-infected erythrocytes was highly stage-specific, as late-stage schizont erythrocytes demonstrated increased uptake relative to ring-stage and early trophozoite erythrocytes. The constrained peptide inhibited recombinant $P f C D P K 1$ in the low micromolar range $\left(\mathrm{IC}_{50}: 3.5 \mu \mathrm{M}\right)$ and caused a significant decrease in parasitemia at concentrations of $\geq 10 \mu \mathrm{M}$.

Lima and co-workers [44] designed and developed shape-based and machine learning models of $P f C D P K 1, P f C D P K 4$ and $P f$ PK6. These models were used for virtual screening of drug-like molecules to identify potent inhibitors with activity against multiple $P$. falciparum kinases. The computational hits were then evaluated in vitro against drug-sensitive (3D7) and multidrug-resistant (Dd2) P. falciparum erythrocytic parasites. Quinazoline derivatives (compounds 8-10, Figure 3) inhibited the growth of both drug-sensitive and multidrug-resistant P. falciparum strains in the nanomolar range. Compounds 8 and $\mathbf{1 0}$ also demonstrated good in vivo inhibition of $P$. berghei ookinete formation at a concentration of $10 \mu \mathrm{M}$. Molecular docking studies indicated that compound 8 was able to interact with PfCDPK1, $P f C D P K 4$ and $P f$ PK6, thus highlighting its potential as a multi-kinase inhibitor.

Another virtual screening campaign against a PfCDPK1 homology model ( $P b C D P K 1$ crystal structure, PBD ID: 3Q5I), identified 18 compounds from the MyriaScreen Diversity Library II that complement the PfCDPK1 ATP-binding site [45]. Two of these compounds, 11 (ST092793) and 12 (S344699) (Figure 4), significantly inhibited recombinant $P f C D P K 1$ and demonstrated in vitro activity against $P$. falciparum erythrocytic parasites. Interestingly, isothermal titration calorimetry and fluorescence spectroscopy showed that $\mathbf{1 1}$ preferentially binds to the inactive conformation of PfCDPK1, thereby locking the enzyme in this state throughout the erythrocytic stage. 


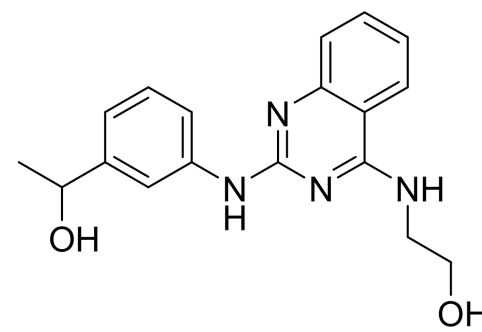

Pf3D7 blood stage EC50 PfDd2 blood stage EC50 $\mathrm{Pb}$ ookinete inhibition
$0.35 \mu \mathrm{M}$

$0.70 \mu \mathrm{M}$

$70.02 \%$

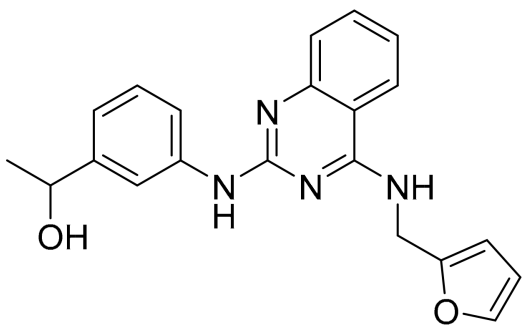

$0.43 \mu \mathrm{M}$

$0.48 \mu \mathrm{M}$

$8.59 \%$

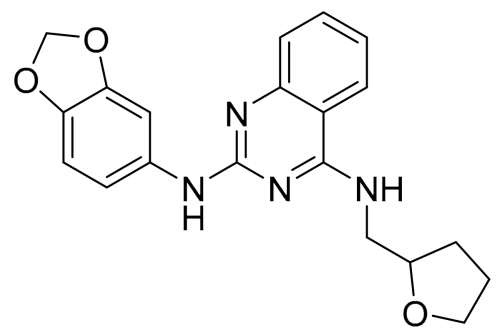

10

$0.39 \mu \mathrm{M}$

$0.40 \mu \mathrm{M}$

$51.81 \%$

Figure 3. Quinazoline derivatives as inhibitors of multiple plasmodial kinases.

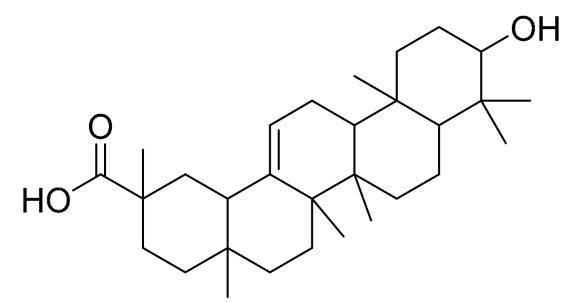

11

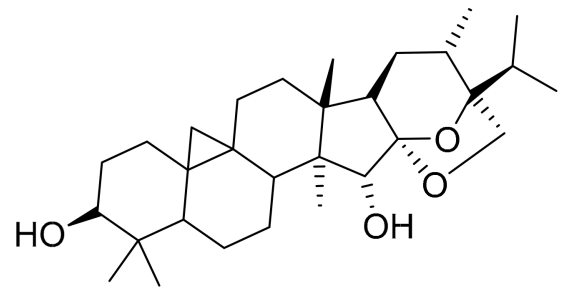

12

$200.0 \mu \mathrm{M}$

$42.6 \mu \mathrm{M}$

$17.8 \mu \mathrm{M}$

Pf3D7 blood stage $\mathrm{EC}_{50}$

$33.8 \mu \mathrm{M}$

$9.5 \mu \mathrm{M}$

Figure 4. Structures and biological data of compounds $\mathbf{1 1}$ and $\mathbf{1 2 .}$ 
Overall, the results from these studies suggest that PfCDPK1 may not be the most suitable target for P. falciparum blood-stage infections. It seems as though the pathways and/or enzymes that are able to compensate for the loss of PfCDPK1 activity [21,23,24] greatly affect the potency of PfCDPK1 inhibitors in vivo. Greater success may be achieved if future drug development focusses on PfCDPK1 as a potential transmission-blocking target.

\subsubsection{PfCDPK4}

As PfCDPK4 is essential for sexual stage development of $P$. falciparum, it is a promising drug target for developing new transmission-blocking antimalarial drugs. The scaffolds explored thus far for PfCDPK4 inhibition include phenothiazines, pyrazolopyrimidines, imidazopyrazines and 5-aminopyrazole-4-carboxamide derivatives [46-50].

Based on pyrazolopyrimidine BKIs designed for Toxoplasma gondii CDPK1 (TgCDPK1) and Cryptosporidium paroum CDPK1 (CpCDPK1), a series of pyrazolopyrimidine derivatives (e.g., compounds 13-15, Figure 5) with potent activity against PfCDPK4 were designed [49,50].

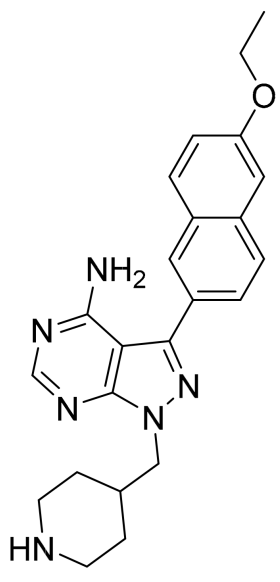

13

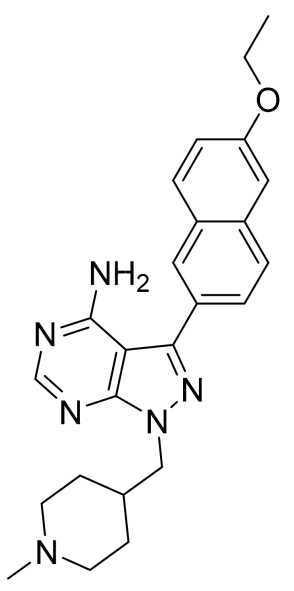

14

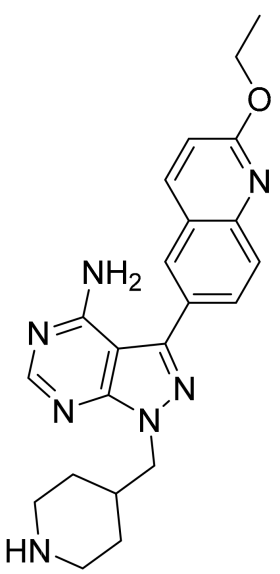

15

$2 \mathrm{nM}$

ND

$<40$ nM
PfNF54 blood stage EC50

PfNF54 exflagellation EC50
$4 \mathrm{nM}$

$2 \mu \mathrm{M}$

$35 \mathrm{nM}$
$10 \mathrm{nM}$

$8 \mu \mathrm{M}$

$47 \mathrm{nM}$

Figure 5. Pyrazolopyrimidine derivatives as inhibitors of PfCDPK4. PfNF54: Plasmodium falciparum NF54 strain.

Minimal off-target activity was observed for some of these compounds when tested against human Src and Abl tyrosine kinases, which both have one of the smallest gatekeeper residues (threonine) in the human kinome $[49,50]$. However, when screened against human non-kinase targets, compound 14 also inhibited the human ether-a-go-go related gene potassium channel (hERG) which is critical for cardiac repolarisation [51]. Pyrazolopyrimidine compounds have been shown to block exflagellation of male gametocytes in P. falciparum parasites [49,50] and in P. berghei-infected mice [49] within the nanomolar range. When Anopheles stephensi mosquitoes were allowed to feed on P. berghei-infected mice treated with compound 13 (10 mg/kg, intraperitoneally), oocyst formation was blocked in the mosquito midgut. Similarly, infective sporozoite formation was inhibited in Anopheles stephensi mosquitoes that fed on PfNF54-infected human blood containing $3 \mu \mathrm{M}$ of compound 13 [49]. P. falciparum parasites expressing PfCDPK4 with a mutated gatekeeper (small serine residue changed to a large methionine residue, S147M), were insensitive to pyrazolopyrimidine-based compounds and demonstrated normal exflagellation, which confirms PfCDPK4 to be the target of these inhibitors $[48,49]$. Substituting the pyrazolopyrimidine scaffold with an imidazopyrazine core generally resulted in similar PfCDPK4 
selectivity and potency [50]. In silico studies revealed the structure-activity relationships of these pyrazolopyrimidine and imidazopyrazine compounds with the PfCDPK4 target [52].

Another scaffold used for TgCDPK1 inhibitor development [53], 5-aminopyrazole-4-carboxamide, was also shown to potently inhibit PfCDPK4 in the nanomolar range [47]. The most active 5-aminopyrazole-4-carboxamide derivatives (compounds 16 and 17, Figure 6) demonstrated potent inhibition of $P$. falciparum male gametocyte exflagellation at a concentration of $0.1 \mu \mathrm{M}$. The in vitro inhibition was much higher than the enzymatic assay predicted, which may indicate multiple targets for these compounds. In terms of selectivity over human kinases, these inhibitors demonstrated high selectivity over Src kinase and hERG.<smiles>CCOc1ccc2cc(-c3nn(C(F)(F)F)c(N)c3C(N)=O)cnc2c1</smiles>

16<smiles>NC(=O)c1c(-c2cnc3cc(OC4CC4)ccc3c2)nn(C(F)(F)F)c1N</smiles>

17

$82 \mathrm{nM}$

$>20 \mu \mathrm{M}$

$84 \%$

Figure 6. 5-Aminopyrazole-4-carboxamide derivatives as inhibitors of PfCDPK4.

Members of the phenothiazine class were identified as possible non-ATP-competitive inhibitors of PfCDPK4 [46]. Trifluoperazine (TFP) (18, Figure 7) was the most active of this class, with a binding affinity $\left(\mathrm{K}_{\mathrm{d}}\right)$ of $134.5 \mu \mathrm{M}$ and $\mathrm{K}_{\mathrm{i}}$ value of $150 \mu \mathrm{M}$ for $P f C D P K 4$. The discrepancy between the enzymatic activity of TFP and the reported in vitro activity $\left(\mathrm{EC}_{50}: 1.9 \mu \mathrm{M}\right)$ against $P$. falciparum indicates that this compound modulates multiple targets.

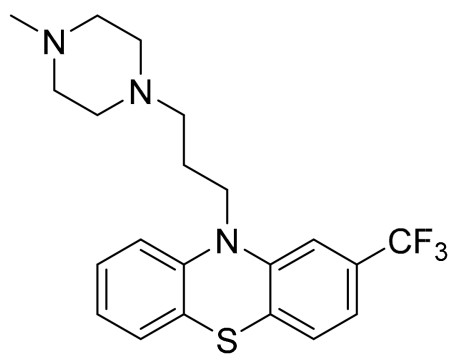

18

PfCDPK4 Ki

Pf blood stage $\mathrm{EC}_{50}$
$150.0 \mu \mathrm{M}$

$1.9 \mu \mathrm{M}$

Figure 7. Structure and biological data of trifluoperazine (TFP). 
Homology modelling indicated that TFP possibly binds to the calmodulin-like domain of PfCDPK4 which prevents repositioning of the autoinhibitory J-domain upon binding of $\mathrm{Ca}^{2+}$, thereby locking the kinase in its inactive state.

\subsection{3. $P f C D P K 5$}

To date, only one study has been published on inhibitor development for PfCDPK5. Rout and Mahapatra predicted the three-dimensional structure of $P f C D P K 5$ through homology modelling using P. berghei CDPK1 as a template [54]. Possible inhibitors of PfCDPK5 were then identified through virtual screening of five different sets of compounds with known antimalarial activity. MMV687246 (19, Figure 8), from the Malaria box assembled by The Medicines for Malaria Venture, demonstrated the highest binding affinity for $P f C D P K 5$ and was suggested as a possible lead for future experimental validation and inhibitor design.

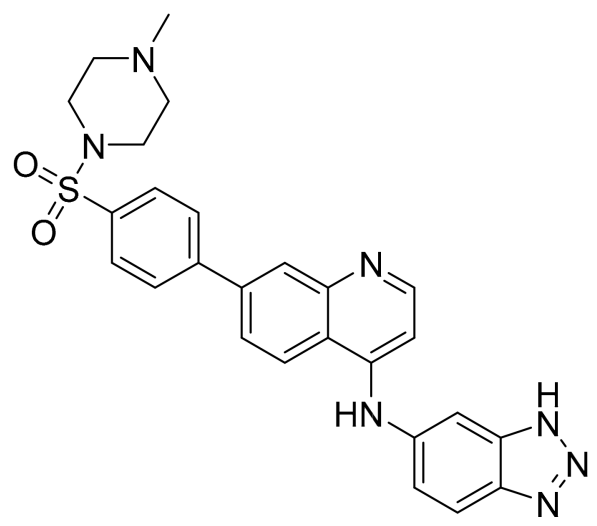

19

$$
\text { PfCDPK5 binding affinity } \quad-11.6 \mathrm{kcal} / \mathrm{mol}
$$

Figure 8. Structure and biological data of MMV687246.

\section{AGC Group}

Three of the five malarial kinases that cluster within this group, namely adenosine monophosphate (cAMP)-dependent protein kinase A (PKA), cyclic guanosine monophosphate (cGMP)-dependent protein kinase $\mathrm{G}(\mathrm{PKG})$ and protein kinase $\mathrm{B}$ (PKB) have been characterised [13]. cAMP-, cGMP- and calcium-mediated signalling pathways are closely linked within the malaria parasite. In merozoites, a rise in cytosolic cAMP levels leads to activation of PKA and an increase in cytosolic calcium levels via induction of the Epac (exchange protein directly activated by cAMP) pathway [55]. When activated by cGMP, PKG regulates phosphoinositide metabolism which produces inositol $(1,4,5)$-triphosphate $\left(\mathrm{IP}_{3}\right)$, a messenger molecule that signals the release of intracellular calcium [56]. The release of calcium in turn activates stage-specific effector pathways, including CDPK signalling [29,56]. In contrast to the other two kinases, PKB is activated by calmodulin in a calcium-dependent manner [57]. Phospholipase $C$ has been identified as the upstream regulator responsible for releasing the calcium required for $\mathrm{PKB}$ activation [57].

During the asexual parasite stages, $P f$ PKA, $P f$ PKG and $P f$ PKB regulate different factors required for parasite invasion and egress. Pf PKA phosphorylates the P. falciparum apical membrane antigen 1 (PfAMA1) which is critical for tight junction formation between the parasite and the host cell during erythrocyte invasion [58-60]. PfPKA has also been implicated in regulation of parasite motility [61], microneme secretion [55], anion channel conductance at the erythrocytic plasma membrane [62] and the cell cycle of the intraerythrocytic parasite [63]. However, Patel and co-workers [60] reported that events prior to invasion, such as egress, rise in cytosolic calcium levels and microneme secretion, can all occur in the absence of cAMP and PfPKA. Apart from merozoite invasion, they also did not observe 
any other critical role for cAMP and PfPKA in the erythrocytic life cycle. PfPKG controls invasion and egress of sporozoites (liver-stage parasites) [29,64] and merozoites (blood-stage parasites) [65-67] by regulating parasite motility and microneme secretion. $P f \mathrm{PKB}$ also plays a role in merozoite invasion of erythrocytes by regulating parasite motility [68]. During the sexual parasite stages, PfPKG regulates gametogenesis, which involves male gamete exflagellation and rounding up of female gametes, and ookinete motility required for mosquito midgut invasion $[56,69,70]$. Both PfPKA and PfPKG have been validated as essential kinases, $P f$ PKA being essential for blood-stage parasites $[58,60]$ and $P f$ PKG being essential for multiple life cycle stages $[67,69,71]$. Pf PKB is regarded as likely essential to blood-stage parasite survival [22].

\subsection{Inhibitor Development for the AGC Group}

\subsubsection{PfPKG}

In terms of inhibitor development, PfPKG is one of the plasmodial kinases that has been studied extensively thus far. It is regarded as a very attractive antimalarial drug target as its inhibition offers simultaneous prophylactic, curative and transmission-blocking potential [72]. As PfPKG is an essential enzyme for multiple life cycle stages, there is a relatively low risk of the parasite developing high-grade resistance to PfPKG-selective inhibitors [72]. The PKG enzyme is also highly conserved in all human malaria species, with an overall sequence identity of $90-92 \%$ and identical catalytic site and gatekeeper residues [73]. Thus, PKG inhibitors have the potential to be active against multiple malaria species. Although human PKG orthologues (cytosolic PKG-I $\alpha$ and PKG-I $\beta$, membrane-associated PKG-II) exist, selective inhibitor development is still possible as there is significant structural divergence between plasmodial and mammalian PKGs [74].

A variety of scaffolds have been explored for PfPKG inhibitor development, with the imidazopyridines $[71,75,76]$ and thiazoles $[73,77,78]$ being the most advanced inhibitors of PfPKG. Compound 20 (Figure 9), a PKG inhibitor of Eimeria tenella [79], was used as a lead compound to develop potent imidazopyridine inhibitors of PfPKG [71,75,76]. Compound 21 (Figure 9) was the most potent of a series of imidazopyridines synthesised by Baker and co-workers [71], with an $\mathrm{IC}_{50}$ value of $0.16 \mathrm{nM}$ against $P f$ PKG and an $\mathrm{EC}_{50}$ value of $2.1 \mathrm{nM}$ against $P$. falciparum blood-stage parasites. Compound 21 demonstrated no toxicity in vitro or in vivo, high selectivity over human kinases and moderate metabolic stability in vitro. Oral administration of compound 21 to P. falciparum-infected mice (twice-daily dose of $100 \mathrm{mg} / \mathrm{kg}$ ) over a period of four days reduced parasitemia below detectable levels. Apart from blood-stage efficacy, compound 21 also inhibited transmission of mature P. falciparum gametocytes to Anopheles stephensi mosquitoes ( $\left.\mathrm{IC}_{50}: 41.3 \mathrm{nM}\right)$.

Subsequent studies focussed on improving the ADME properties of this chemical class while retaining potent inhibitory activity. By means of structure-activity relationship and modelling studies, Large and co-workers $[75,76]$ systematically varied the substituents of compound 20 and explored other bicyclic cores. Compounds 22 [75] and 23 [76] (Figure 9) retained the potent PfPKG and in vitro antimalarial activity of compound 20. Compound 22 also retained the $\log \mathrm{D}$ and lipophilic ligand efficiency of compound 20, and showed improved permeability, but demonstrated poor stability in mouse liver microsomes [75]. Compound 23 demonstrated an excellent balance of activity and physicochemical properties. In addition to good LogD and LLE, compound 23 showed improved microsomal stability and excellent selectivity over human kinases, including the two human PKG orthologues (PKG1 $\alpha$ and PKG1 $\beta$ ) [76].

A 2,3-diaryl-pyrrole inhibitor of PKG developed for Eimeria tenella (compound 24, Figure 10) [80] was shown to be a potent inhibitor of PfPKG $\left(\mathrm{IC}_{50}\right.$ : $\left.3.5 \mathrm{nM}\right)$ [81]. However, compound 24 only demonstrated modest in vitro activity against $P$. falciparum and failed to reduce parasitemia in a P. berghei mouse model [81]. A scaffold-hopping approach performed on compound 24 lead to the identification of thiazoles (compound 25) as PfPKG inhibitors [78]. Substitution of the thiazole scaffold was optimised to improve the enzymatic and in vitro activity of compound 25 , which lead to compound 
26 ( $\mathrm{IC}_{50}: 2 \mathrm{nM}, \mathrm{EC}_{50}: 113 \mathrm{nM}$ ) [78]. Compound 26 demonstrated excellent selectivity over human kinases, good permeability and metabolic stability in mouse and human liver microsomes.

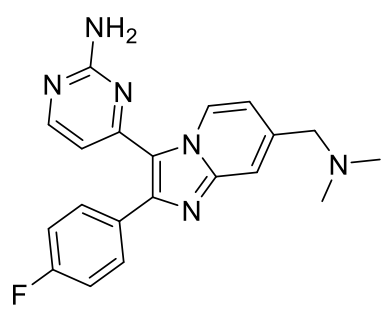

20

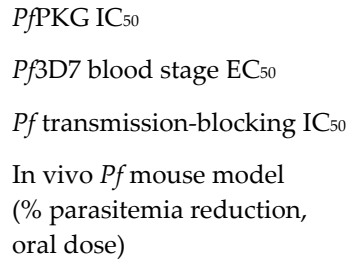<smiles>CN(C)Cc1ccn2c(-c3ccnc(N)n3)c(-c3ccc(F)cc3)nc2c1</smiles>

$3.1 \mathrm{nM}$

$395.0 \mathrm{nM}$

$507.3 \mathrm{nM}$

ND

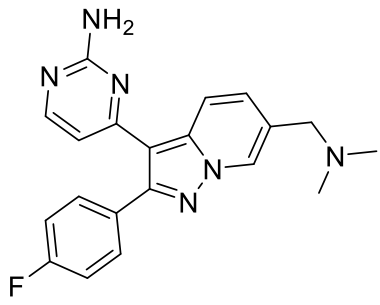

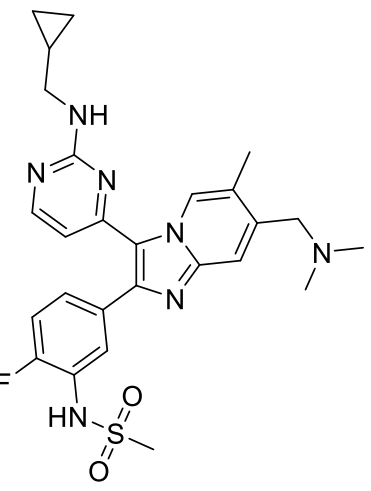

21

$0.16 \mathrm{nM}$

$2.10 \mathrm{nM}$

$41.3 \mathrm{nM}$

99.9\%

$100 \mathrm{mg} / \mathrm{kg}$

Twice daily, 4 days<smiles>CNc1nccc(-c2c(-c3ccc(F)cc3)nc3cc(NCCN(C)C)ccn23)n1</smiles>

23

8.6

6.4

2.2

93\%

MLM

2.4

2.5

$22 \%$

Figure 9. Imidazopyridine-based compounds as inhibitors of PfPKG. $\mathrm{pI}_{50}$ : negative log of the $\mathrm{IC}_{50}$ value in molar; LLE: lipophilic ligand efficiency; LogD: distribution coefficient; MLM: \% remaining after 30 min incubation with mouse live microsomes. 


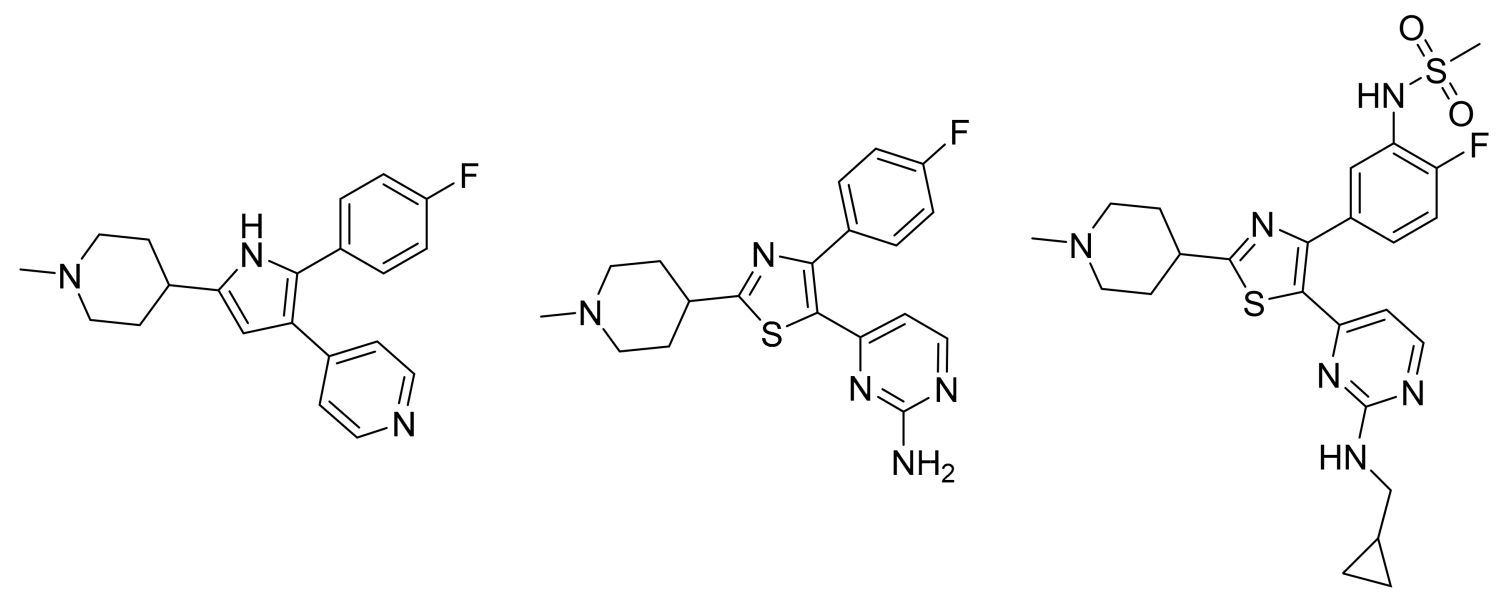

24

25

26

PfPKG IC50

Pf3D7 blood stage EC50

$3.5 \mathrm{nM}$

$490 \mathrm{nM}$
$17 \mathrm{nM}$

$1.8 \mu \mathrm{M}$
$2 \mathrm{nM}$

$113 \mathrm{nM}$

Figure 10. 2,3-Diaryl-pyrrole and thiazole compounds as inhibitors of PfPKG. 
During a high-throughput screening campaign, Penzo and co-workers [73] also identified several thiazole derivatives, such as compound 27 (Figure 11), with nanomolar potencies against PfPKG [73]. The in vitro activity of the most potent compounds was studied at 48 and $72 \mathrm{~h}$ in wild-type and transgenic (PfPKG gatekeeper mutant, T618Q) P. falciparum blood-stage parasites, and the $\mathrm{EC}_{50}$ values against the two strains were very similar-indicating that the thiazole derivatives also inhibit targets other than PfPKG. Additional targets identified for compound 27 included CDPK1, CDPK4, CDK-related kinase (Pfcrk-5), NIMA-related kinase (Pfnek-1), CK1 and an unnamed putative protein kinase (Pf3D7_0926100). Compound 27 also demonstrated good solubility, no toxicity against HepG2 cells, and selectivity over the human PKG orthologue (PKGI $\alpha$ ), human lymphocyte-specific protein tyrosine kinase (LCK) and human Aurora B kinase. Besides blood-stage activity, compound 27 also had potent activity against male and female gametes.

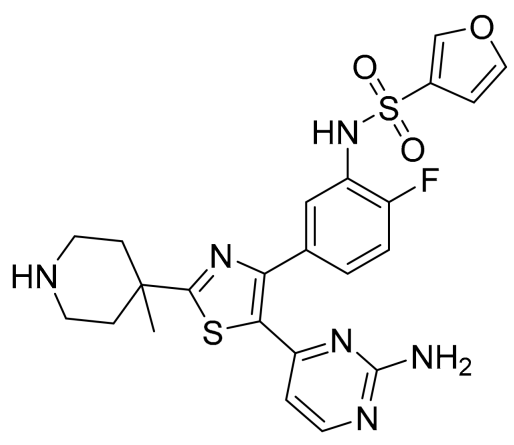

27

PfPKG IC 50

Pf3D7 blood stage $\mathrm{IC}_{50}$ at $48 \mathrm{~h}$

Pf3D7 blood stage $\mathrm{IC}_{50}$ at $72 \mathrm{~h}$

PfNF54 male gamete IC 50

PfNF54 female gamete $\mathrm{IC}_{50}$
$0.8 \mathrm{nM}$

$0.19 \mu \mathrm{M}$

$0.17 \mu \mathrm{M}$

$0.5 \mu \mathrm{M}$

$0.8 \mu \mathrm{M}$<smiles>Cc1cc(Nc2nccc(-c3sc(C4CCNCC4)nc3-c3ccc(F)cc3)n2)ccn1</smiles>

28

$4.4 \mathrm{nM}$

$0.13 \mu \mathrm{M}$

$0.09 \mu \mathrm{M}$

$0.3 \mu \mathrm{M}$

$0.4 \mu \mathrm{M}$

Figure 11. Thiazole derivatives as inhibitors of multiple plasmodial kinases.

Matralis and co-workers [77] specifically focussed on developing a series of thiazole derivatives with a fast-killing profile similar to that of artemisinins. Compound 28 (Figure 11) was the most potent in this series, with in vitro nanomolar activity against PfPKG, P. falciparum blood-stage parasites and gametocytes. It also possessed good physicochemical properties. Despite good selectivity over human enzymes, ion channels and receptors, this compound showed activity towards hERG. Parasite reduction ratio studies demonstrated that compound $\mathbf{2 8}$ had fast-killing properties similar to those of artesunate. CDPK1, CDPK4 and serine/arginine protein kinase 2 (SRPK2, also known as CLK2) were identified as additional targets of compound 28. The fast-killing activity of compound $\mathbf{2 8}$ was mainly attributed to SRPK2 inhibition. This study demonstrates the potential of simultaneously targeting PfPKG and SRPK2 to develop fast-killing drugs with curative and transmission-blocking activity. 
Vanaerschot and co-workers [72] identified $P f P K G$ as the primary target of the Medicines for Malaria Venture compound MMV030084 (29, Figure 12). MMV030084 had an $\mathrm{IC}_{50}$ value of $0.4 \mathrm{nM}$ against recombinant $P f$ PKG, and docking studies using the PfPKG crystal structure (PDB ID: 5DYK) showed a strong interaction between MMV030084 and the ATP-binding site. When evaluated against the different life cycle stages of the parasite, MMV030084 inhibited sporozoite invasion of hepatocytes, merozoite egress from mature schizonts, and male gamete exflagellation. MMV030084 inhibited liver cell invasion by $P$. berghei parasites $\left(\mathrm{IC}_{50}: 199 \mathrm{nM}\right)$ with minimal toxicity against the host cells $\left(\mathrm{CC}_{50}\right.$ : $41.5 \mu \mathrm{M}$ ). The development of P. falciparum blood-stage parasites was halted at the schizont stage when treated with MMV030084 (drug-sensitive strain $\mathrm{IC}_{50}: 109 \mathrm{nM}$; multidrug-resistant strain $\mathrm{IC}_{50}: 120 \mathrm{nM}$ ). Male gamete exflagellation of the P. falciparum NF54 strain was inhibited by MMV030084 with an $\mathrm{IC}_{50}$ value of $141 \mathrm{nM}$. In vitro MMV030084 resistance selection studies identified P. falciparum tyrosine kinase-like 3 (PfTKL3) as an MMV030084-resistance mediator, which allows merozoite egress from erythrocytes when mutated. No mutation was identified for PfPKG itself.

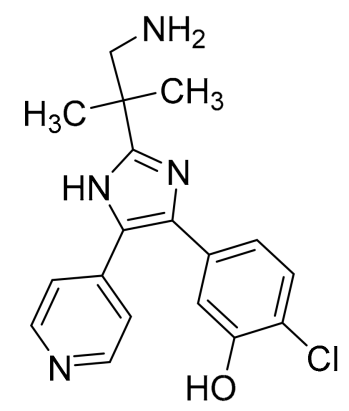

29

$\begin{array}{lc}\text { PfPKG IC50 } & 0.4 \mathrm{nM} \\ \text { Pf3D7 blood stage IC50 } & 109 \mathrm{nM} \\ \text { PfDd2 blood stage } \mathrm{IC}_{50} & 120 \mathrm{nM} \\ \text { Pb liver stage IC50 } & 199 \mathrm{nM} \\ \text { PfNF54 male gamete IC } 50 & 141 \mathrm{nM}\end{array}$

Figure 12. Structure and biological data of MMV030084.

A screening campaign by Mahmood and co-workers [82] identified isoxazole-based inhibitors with PfPKG activity and selectivity over human PKG. Optimisation of this scaffold led to compounds 30-32 (Figure 13) with $\mathrm{IC}_{50}$ values $<20 \mathrm{nM}$ against $P f$ PKG. Further evaluation of the physicochemical properties and in vitro activity of these compounds against the whole-cell parasite has not yet been reported. 


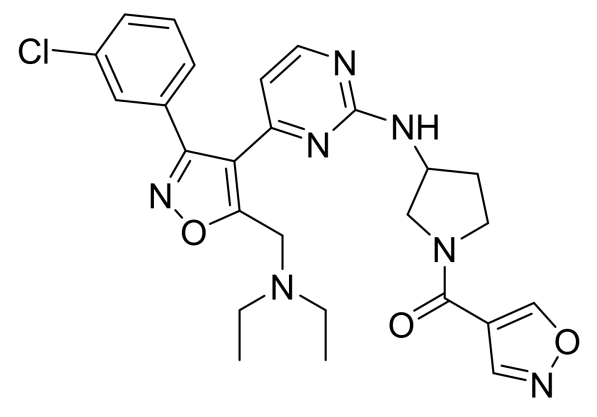

30

PfPKG IC50

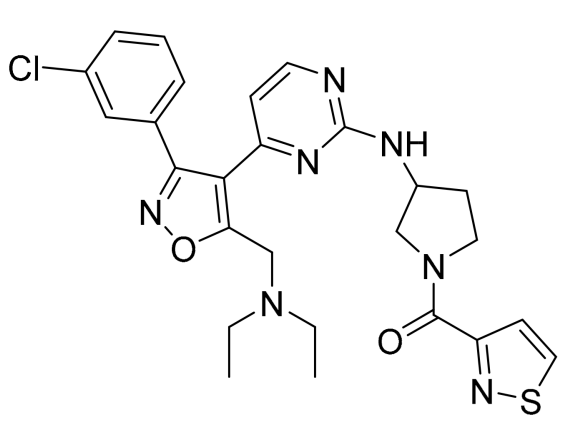

31

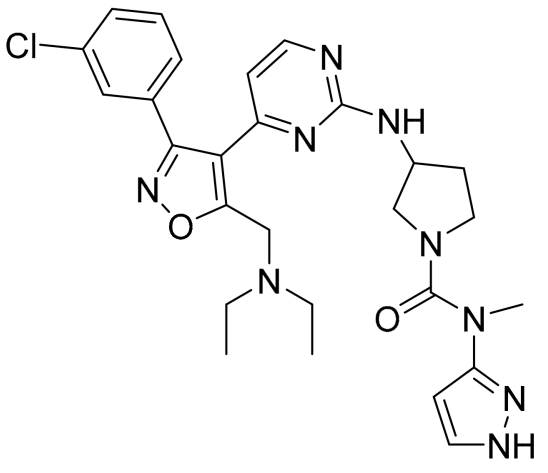

32

$10 \mathrm{nM}$

Figure 13. Isoxazole-based inhibitors of PfPKG. 


\subsection{2. $P f \mathrm{PKA}$ and $P f \mathrm{PKB}$}

Drug discovery efforts targeting PfPKA and Pf PKB are limited. Buskes and co-workers [83] attempted to develop PfPKA inhibitors using the commercially available PKA inhibitor 3-methylisoquinoline4-carbonitrile (33, Figure 14) as a starting point. They studied the interactions of compound $\mathbf{3 3}$ and a series of substituted isoquinolines (e.g., 34, Figure 14) with a PfPKA homology model. In vitro evaluation of this series demonstrated low micromolar activity against drug-sensitive (3D7) and -resistant (W2) P. falciparum strains. However, biochemical evaluation of this series showed minimal activity against PKA [84]. It was suggested that these compounds likely inhibit another kinase that is involved in parasitic cytokinesis and erythrocyte invasion [84].<smiles>Cc1ncc2ccccc2c1C#N</smiles>

33

Rat PKA IC50: $30 \mathrm{nM}$<smiles>CCC(CC)Nc1nc(C)c(C#N)c2ccccc12</smiles>

34

Pf3D7 blood stage EC50: $1.0 \mu \mathrm{M}$

PfW2 blood stage EC 50: $0.7 \mu \mathrm{M}$

Residual human PKA activity: 92\%

Figure 14. 3-Methylisoquinoline-4-carbonitrile derivatives and their biological data.

As PfPKB shares high sequence homology with the catalytic sites of mammalian PKB and protein kinase C (PKC), established PKB and PKC inhibitors were tested for activity against PfPKB. Go 6983 (35, Figure 15), a PKC inhibitor, was shown to inhibit $P f \mathrm{PKB}\left(\mathrm{IC}_{50}: \pm 1 \mu \mathrm{M}\right)$ and significantly reduce P. falciparum parasite growth at the late schizont stage [85]. The mammalian PKB inhibitor A443654 (36, Figure 15) inhibited $P f \mathrm{PKB}$ with an $\mathrm{IC}_{50}$ value of $200 \mathrm{nM}$ [57]. Incubation of $P$. falciparum schizonts with A443654 did not affect the morphology or the number of schizonts but dramatically reduced the number of ring-stage parasites formed after invasion. This indicates that A443654 blocks invasion, which corroborates the function of $P f \mathrm{PKB}$ in erythrocytic invasion. A peptide inhibitor that corresponds to the pseudosubstrate motif of the PfPKB N-terminal effectively inhibited PfPKB activity and also reduced the formation of P. falciparum ring-stage parasites [57].

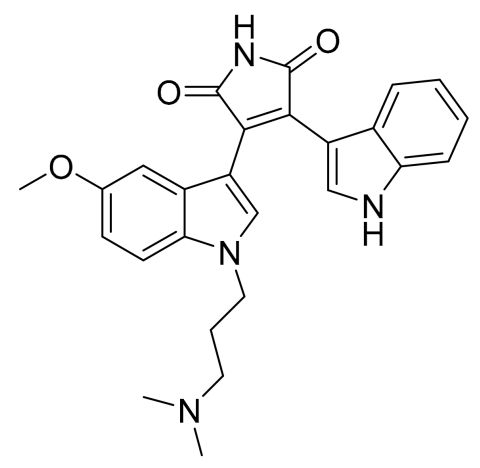

35<smiles>Cc1[nH]nc2ccc(-c3cncc(OCC(N)Cc4c[nH]c5ccccc45)c3)cc12</smiles>

36

PfPKB IC50

$1 \mu \mathrm{M}$

$200 \mathrm{nM}$

Figure 15. Structures and biological data of Go 6983 and A443654. 
Crystal structures of PfPKA's regulatory subunit (PDB ID: 5K8S, 5KBF and 5T3N) [86] and methods for expression and purification of active recombinant $P f$ PKAr (regulatory subunit) [86] and $P f$ PKAc (catalytic subunit) [87] are available for future drug development efforts for this target. The crystal structure of $P f \mathrm{PKB}$ is not yet available; however, the full-length $P f \mathrm{PKB}$ gene has been successfully expressed and purified as an active recombinant protein $[57,68,85]$.

\section{CMGC Group}

The CMGC kinase family consists of cyclin-dependent kinases (CDKs), mitogen-activated protein kinases (MAPKs), glycogen synthase kinase-3 (GSK-3) and CDK-like kinases (CLKs).

\subsection{Cyclin-Dependent Kinases (CDKs)}

Eukaryotic cyclins and CDKs are essential regulators of the cell cycle [88]. Several CDK homologues have been identified in the P. falciparum parasite, namely protein kinase 5 (PfPK5), protein kinase 6 (PfPK6), MO15-related kinase (Pfmrk) and the CDK-related kinases (Pf crk-1, Pf crk-3, Pf crk-4, $P f$ crk-5) $[88,89]$.

PfPK5 is most related to mammalian CDK1 and CDK5 [90] and demonstrates sensitivity to mammalian CDK1/CDK2 inhibitors [91]. It has been proposed that $P f \mathrm{PK} 5$ is likely involved in the regulation of DNA replication (S-phase of the cell cycle) during erythrocytic schizogony $[90,92,93]$. Pf mrk, a putative homologue of mammalian CDK7, is predominantly expressed in gametocytes and to a lesser extent in the asexual stages (trophozoites and schizonts) [94]. Pf mrk is localised in the nucleus of the parasite and is presumably involved in the regulation of DNA replication [95]. $P f$ crk-1 and $P f$ crk-3 display maximal homology to mammalian CDKs involved in transcriptional control $[13,96]$. Pfcrk-1 is mainly expressed in gametocytes [97]; however, the P. berghei orthologue (Pbcrk-1) was found to be essential for erythrocytic schizogony [98]. $P f$ crk-3 has been demonstrated to be essential to erythrocytic parasites and presumably regulates gene expression via interaction with chromatin modification enzymes [96]. $P f$ crk-4 is another essential enzyme for asexual proliferation and also plays a critical role in ookinete formation and early oocyst development [22,99]. Two atypical CDKs, namely PfPK6 and $P f$ crk-5, demonstrate both CDK and mitogen-activated protein kinase (MAPK) homology [100,101]. Nuclear and cytoplasmic localisation have been reported for PfPK6 in trophozoite and schizont parasites [100]. Unlike $P f$ PK5 and $P f$ mrk which are activated by various cyclins in vitro [102,103], $P f$ PK6 appears to be a cyclin-independent kinase [100]. $P f$ crk-5 is a cyclin-dependent enzyme localised in the nuclear periphery [101]. Although parasites lacking $P f c r k-5$ are viable, they display decreased erythrocytic proliferation due to a lower number of merozoites released per schizont [101].

\subsubsection{CDK Inhibitor Development}

\section{PfPK5}

Developing $P f$ PK5-selective inhibitors is quite challenging due to the high degree of homology between PfPK5 and the human CDKs. Eubanks and co-workers [104] demonstrated that a target-based screening approach was more effective to identify $P f$ PK5-selective inhibitors than chemically modifying existing CDK inhibitors. The 4-methylumbelliferone analogues, compounds 37 and $\mathbf{3 8}$ (Figure 16), demonstrated a 2-fold binding affinity for PfPK5 over human CDK2 (HsCDK2). No significant toxicity was observed against human hepatoma cell lines (HuH7 and HepG2) for either compound. However, both compounds failed to inhibit drug-resistant P. falciparum (Dd2 strain) asexual parasite growth in vitro, most likely due to poor physicochemical properties. 
<smiles>Cc1cc(=O)oc2c(/C=N/C3CCCCC3)c(O)ccc12</smiles>

37

PfPK5 Kd(app)

$\mathrm{HsCDK}_{2} \mathrm{Kd}_{\mathrm{d}(\mathrm{app})}$

PfDd2 blood stage $\mathrm{EC}_{50}$
$5 \mu \mathrm{M}$

$14 \mu \mathrm{M}$

$>20 \mu \mathrm{M}$<smiles>Cc1cc(=O)oc2c(/C=N/C3CCC(I)CC3)c(O)ccc12</smiles>

38

$28 \mu \mathrm{M}$

$>20 \mu \mathrm{M}$

Figure 16. 4-Methylumbelliferone inhibitors of $P f \mathrm{PK} 5$ and their biological data. $\mathrm{K}_{\mathrm{D}(\mathrm{app})}$ : apparent dissociation constant.

Pf mrk

Scaffolds studied for $P f$ mrk inhibition include quinolinones [105], oxindoles [106], chalcones [107], flavonoids [108] and sulfonamide-based compounds [109-111].

A series of quinolinones (e.g., compound 39, Figure 17) demonstrated $P f$ mrk activity with $\mathrm{IC}_{50}$ values ranging from 18 to $539 \mu \mathrm{M}$ [105]. Neither antimalarial evaluation against whole-cell parasites nor molecular docking has been performed for this chemical class. Based on the structure of commercially available indirubin- $3^{\prime}$-monoxime, a moderate inhibitor of $P f \mathrm{mrk}$ and in vitro $P$. falciparum parasite growth, oxindole-based compounds were explored as inhibitors of $P f$ mrk [106]. Several oxindoles selectively inhibited $P f$ mrk in the low micromolar range, with the most potent being compound 40 (Figure 17). None of the oxindoles demonstrated any significant in vitro activity against whole-cell parasites. Homology modelling showed that these compounds had the same orientation in the active site of $P f$ mrk as in human CDK2, but with additional contact points which might be responsible for the Pf mrk specificity.<smiles>O=c1[nH]c2ccccc2cc1-c1cccc(OCCO)c1</smiles>

39<smiles>O=C(CC1C(=O)Nc2ccc(Br)cc21)c1ccc(F)cc1</smiles>

40
Pfmrk IC 50

PfD6 blood stage $\mathrm{EC}_{50}$

PfW2 blood stage EC50
$18 \mu \mathrm{M}$

ND

ND
$1.4 \mu \mathrm{M}$

$>14.4 \mu \mathrm{M}$

$>14.4 \mu \mathrm{M}$

Figure 17. Quinolinone and oxindole derivatives as inhibitors of $P f$ mrk. 
The chalcone and sulfonamide-based scaffolds were identified by means of a three-dimensional structure-activity relationship (3D-QSAR) pharmacophore model [109,112]. Compound 41 (Figure 18) was the most active compound of a series of chalcones tested against Pfmrk (IC $\left.5_{50}: 1.3 \mu \mathrm{M}\right)$ [107]. However, a weak correlation was observed between the Pfmrk activity and the in vitro activity against drug-sensitive (D6) and -resistant (W2) P. falciparum strains. As several mechanisms of action have been reported for the antimalarial activity of chalcones [113-115], Geyer and co-workers [107] proposed that $P f$ mrk inhibition might be an additional mechanism demonstrated by some chalcones. Several flavonoids isolated from Erythrina sp., were evaluated for activity against $P f$ mrk [108]. The most potent flavonoid, Abyssinone V (42), had an $\mathrm{IC}_{50}$ value of $0.038 \mu \mathrm{M}$. Despite potent Pfmrk activity, the flavonoids demonstrated similar in vitro antimalarial activity to that of the chalcones, presumably due to the lower permeability of the flavonoids.<smiles>COc1ccc(C(=O)/C=C/c2cccc3ccccc23)c(OC)c1</smiles>

41

Pfmrk IC 50

PfD6 blood stage EC 50

PfW2 blood stage EC50
$1.3 \mu \mathrm{M}$

$4.9 \mu \mathrm{M}$

$4.6 \mu \mathrm{M}$<smiles>CC(C)=CCc1cc(C2CC(=O)c3c(O)cc(O)cc3O2)cc(CC=C(C)C)c1O</smiles>

42

$0.04 \mu \mathrm{M}$

$2.4 \mu \mathrm{M}$

$3.6 \mu \mathrm{M}$

Figure 18. Structures and biological data of chalcone and flavonoid-based inhibitors of $P f \mathrm{mrk}$.

Isoquinoline sulfonamides were generally weak inhibitors of Pfmrk, except compound 43 (Figure 19) which demonstrated an $\mathrm{IC}_{50}$ value of $0.7 \mu \mathrm{M}$ [111]. However, compound 43 failed to inhibit drug-sensitive (D6) and -resistant (W2) P. falciparum parasite growth. Thiophene sulfonamides exemplified by 44 and 45 (Figure 19) were found to be potent inhibitors of Pfmrk with $\mathrm{IC}_{50}$ values in the submicromolar range [110]. However, all of these compounds, except compound 45, are also potent inhibitors of human CDK7. Thiophene sulfonamides demonstrated minimal cytotoxicity and moderate in vitro activity against a multidrug-resistant $P$. falciparum (W2) strain.<smiles>NCCNS(=O)(=O)c1cccc2cnccc12</smiles>

43<smiles>Cc1ccc(S(=O)(=O)Nc2cccc(C(F)(F)F)c2)cc1</smiles>

44<smiles>O=C(CBr)N(c1ccccc1)S(=O)(=O)c1cc(Cl)sc1Cl</smiles>

45

$0.6 \mu \mathrm{M}$

ND

$23.3 \mu \mathrm{M}$

PfD6 blood stage EC50

$0.7 \mu \mathrm{M}$

$0.7 \mu \mathrm{M}$

ND

$>72 \mu \mathrm{M}$

$31.7 \mu \mathrm{M}$

Figure 19. Sulfonamide-based inhibitors of $P f$ mrk. 


\section{PfPK6 and CDK-Related Kinases}

To our knowledge, no medicinal chemistry campaigns have focussed on drug development for $P f$ PK6 and the CDK-related kinases ( $P f$ crk-1 to -5). Homology models have been developed for $P f$ PK6 [116,117] and $P f$ crk-4 [99], which can be used for virtual screening of small-molecule inhibitors against these targets. Methods for expression and purification of active recombinant PfPK6 [100], $P f$ crk-1 (kinase domain) [118], $P f$ crk-3 [96] and $P f$ crk-5 [101] are also available in the literature.

\subsection{Mitogen-Activated Protein Kinases (MAPKs)}

The P. falciparum kinome encodes two MAPK homologues, namely Pfmap-1 and Pfmap-2. Interestingly, $P f$ map-2 is essential for the asexual stages of $P$. falciparum parasites [119]; however, the $P$. berghei orthologue (Pbmap-2) is only essential for male exflagellation in the mosquito midgut [120]. $P f$ map-1 also plays an important role during asexual development; however, parasites are able to compensate for loss of $P f$ map-1 activity by upregulating $P f$ map-2 [119].

Human p38 MAPK inhibitors have been shown to inhibit drug-sensitive (HB3) and -resistant P. falciparum strains in vitro; however, antiplasmodial activity has yet to be attributed to plasmodial MAPK inhibition [121].

\subsection{Glycogen Synthase Kinase-3 (GSK-3)}

PfGSK-3 is one of three GSK3-related kinases identified in the P. falciparum parasite [13]. Although $P f G S K-3$ is expressed throughout the erythrocytic stage, it is predominantly expressed during the early trophozoite stage [122]. After expression, PfGSK-3 is rapidly transported to the cytoplasm of the erythrocyte where it appears to associate with membranous structures known as Maurer's clefts [122]. The exact biological functions of PfGSK-3 remain to be elucidated; however, it has been demonstrated to be essential for the survival of asexual erythrocytic parasites [22].

\section{PfGSK-3 Inhibitor Development}

Despite the high degree of homology between PfGSK-3 and mammalian GSK-3, significant structural differences exist that can be exploited for PfGSK-3-selective inhibition [122-125]. Fugel and co-workers [123] designed a novel series of 4-phenylthieno [2,3-b]pyridine based on structures of hits (e.g., compound 46, Figure 20) identified during a high-throughput screening campaign. Compounds from this series, such as compound 47 (Figure 20), selectively inhibited PfGSK-3 (IC 50 : $0.48 \mu \mathrm{M}$ ) over human GSK-3 (GSK-3 $\alpha$ IC $_{50}:>100 \mu \mathrm{M}$; GSK-3 $\beta$ IC $_{50}: 3.3 \mu \mathrm{M}$ ) and demonstrated broad selectivity when tested against two panels of mammalian kinases. Compound 47 also had in vitro activity against erythrocytic P. falciparum (NF54-Luc) parasites $\left(\mathrm{EC}_{50}: 5.5 \mu \mathrm{M}\right)$. Masch and co-workers [126] improved the solubility and antimalarial activity of the 4-phenylthieno[2,3-b]pyridine compounds by attaching an additional aliphatic polar side chain to the para-position of the 4-phenyl ring. Compared to compound $\mathbf{4 7}$, compound 48 (Figure 20) exhibited 4.5-fold higher antiplasmodial activity against erythrocytic $P$. falciparum (NF54-Luc) parasites $\left(\mathrm{EC}_{50}: 1.2 \mu \mathrm{M}\right)$, as well as improved solubility (47: $4.8 \mu \mathrm{M} ; 48: 1.5 \mu \mathrm{M})$. Recently, we identified a series of benzofuran-based compounds as potent and selective inhibitors of PfGSK-3 ([127], submitted for publication). The most promising benzofurans, compounds 49 and 50 (Figure 20), inhibit PfGSK-3 in nanomolar concentrations and demonstrate 316-fold and 175-fold selectivity for PfGSK-3 over human GSK-3. 


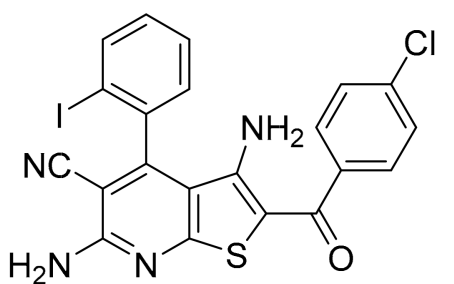

46

PfGSK-3 IC50

Mammalian GSK-3 $\beta$ IC 50 PfNF54 blood stage EC50
$1.6 \mu \mathrm{M}$

$>100 \mu \mathrm{M}$

ND

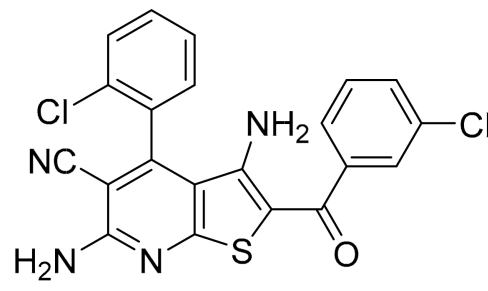

47

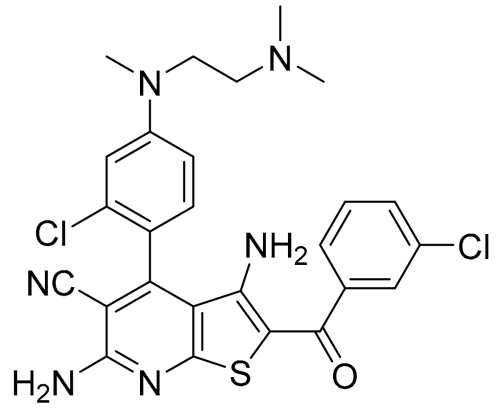

48
$0.5 \mu \mathrm{M}$

$3.3 \mu \mathrm{M}$
$0.7 \mu \mathrm{M}$

$40.2 \mu \mathrm{M}$

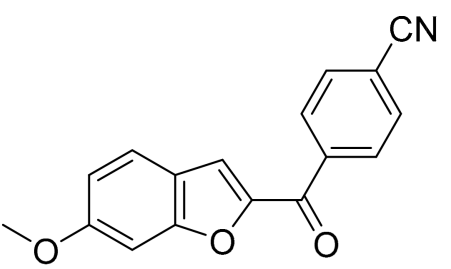

49

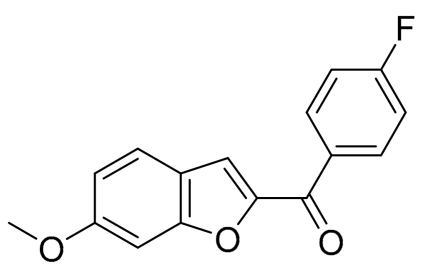

50

PfGSK-3 IC 50

$0.5 \mathrm{nM}$

$1.7 \mathrm{nM}$

Human GSK-3 $\beta$ IC50

$155.0 \mathrm{nM}$

$294.0 \mathrm{nM}$

Figure 20. 4-Phenylthieno[2,3-b]pyridine and benzofuran-based inhibitors of PfGSK-3. 


\subsection{CDK-Like Protein Kinases (CLKs)}

Four members of the CLK family have been identified in P. falciparum, PfCLK-1 to -4 [13]. All four enzymes are essential to the asexual erythrocytic parasites [22,128] as they regulate mRNA splicing through phosphorylation of serine/arginine-rich (SR) proteins [129]. PfCLK1 and PfCLK2 exhibit homology to the yeast SR protein, Sky1p, and are expressed throughout the erythrocytic stage and in gametocytes [128]. Both kinases are localised within the nucleus of the parasite, with PfCLK2 also present in the cytoplasm [128]. PfCLK3 is a closely related homologue of human pre-mRNA processing factor 4B (PRP4 or PRPF4B) [130] which regulates mRNA splicing through phosphorylation of proteins associated with the spliceosome complex [131]. PfCLK4, also known as SR protein-specific kinase 1 (SRPK1), is expressed in erythrocytic parasites and abundantly in gametocytes [132,133]. PfCLK4 negatively regulates mRNA splicing by phosphorylating a putative plasmodial SR protein (PfSR1) in vitro [132,134]. Both PfCLK4 and PfSR1 are localised inside the nucleus of ring and early trophozoite stage parasites. As erythrocytic development progresses, the two proteins are exported to the nuclear periphery (mature trophozoites) and finally to the cytoplasm (schizonts and gametocytes) [132,134].

CLK Inhibitor Development

A high-throughput screening campaign identified TCMDC-135051 (51, Figure 21) as a highly potent and selective inhibitor of PfCLK3 [135]. TCMDC-135051 demonstrated selectivity for PfCLK3 over closely related human kinases (CLK2 and PRPF4B), the closest related plasmodial kinase (PfCLK1) and two other plasmodial kinases (PfPKG and PfCDPK1). PfCLK3 mutations were observed in P. falciparum parasites with reduced sensitivity to TCMDC-135051, which indicated that PfCLK3 was the primary target of this compound. A recombinant PfCLK3 variant with a G449P mutation and parasites expressing the G449P mutant PfCLK3 both demonstrated reduced TCMDC-135051 sensitivity, confirming that the antimalarial activity of TCMDC-135051 was due to PfCLK3 inhibition. TCMDC-135051 inhibition resulted in downregulation of 425 essential $P$. falciparum genes and upregulation of certain genes involved in RNA processing, which is consistent with the proposed mRNA splicing role of PfCLK3. TCMDC-135051 was active against multiple stages of the parasite's life cycle, including liver-stage sporozoites, blood-stage parasites, gametocyte development and subsequent transmission to the mosquito vector. TCMDC-135051 also demonstrated activity against CLK3 of P. vivax (PvCLK3) and P. berghei (PbCLK3), as well as in vitro activity against $P$. knowlesi and $P$. berghei blood-stage parasites. A dose-dependent reduction in parasitemia was observed when TCMDC-135051 was administered intraperitoneally to P. berghei-infected mice (twice daily, 5-day period), with the maximal dose $(50 \mathrm{mg} / \mathrm{kg})$ reducing parasitemia below detectable levels. 


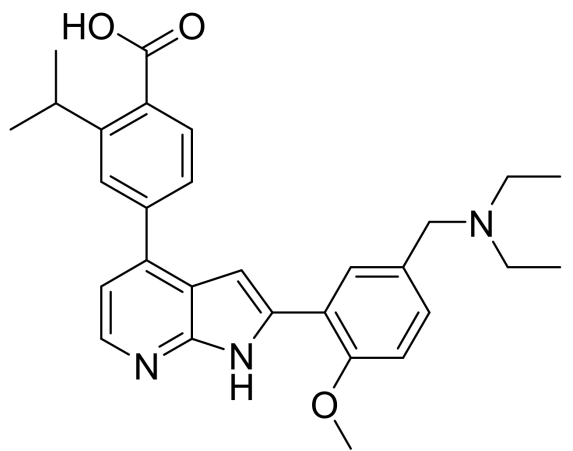

PfCLK3 IC 50

PvCLK3 IC50

$\mathrm{PbCLK3} \mathrm{IC}_{50}$

PfDd2 blood stage EC50

$\mathrm{Pb}$ liver sporozoites $\mathrm{EC}_{50}$

In vivo $\mathrm{Pb}$ mouse model

(\% parasitemia reduction, peritoneal dose)
51

51
$40 \mathrm{nM}$
$33 \mathrm{nM}$
$13 \mathrm{nM}$
$450 \mathrm{nM}$
$400 \mathrm{nM}$
$99.9 \%$
$50 \mathrm{mg} / \mathrm{kg}$
Twice daily, 5 days

Figure 21. Structure and biological data of TCMDC-135051.

\section{Casein Kinase 1 (CK1) Group}

The $P$. falciparum kinome encodes a single CK1 enzyme (PfCK1) that is expressed throughout the erythrocytic stages. $P f C K 1$ is essential for blood-stage parasite survival [22] and is likely involved in cellular processes such as mRNA splicing, protein trafficking and erythrocyte invasion [136,137]. To our knowledge, no medicinal chemistry programs have targeted this enzyme thus far.

\section{NIMA- and Aurora-Related Kinases}

Four Never in Mitosis, gene A (NIMA)-related kinases or NEKs (Pfnek-1 to -4) [12,13] and three Aurora-related kinases ( $P f$ ark-1 to -3) [138] have been identified for P. falciparum. Both groups of kinases are involved in the regulation of the parasitic cell cycle [88,139]. Pfnek-1 and the three Aurora-related kinases are likely essential for erythrocytic schizogony, while $P f$ nek- 2 and $P f$ nek-4 are essential for sexual development of the parasite [139].

With regards to inhibitor development, compounds (e.g., 52 and 53, Figure 22) isolated from marine sponges were found to inhibit $P f$ nek- 1 and demonstrate in vitro $P$. falciparum activity [140-142]. Human Aurora kinase inhibitors also demonstrated antiplasmodial activity in vitro; however, the activity is yet to be attributed to plasmodial Aurora-related kinase inhibition [143]. 
<smiles>CC12CCCc3coc(c31)C(=O)c1cc3c(cc12)C(=O)C=CC3=O</smiles>

52

Pfnek-1 IC50

PfFCB1 blood stage EC50
$1 \mu \mathrm{M}$

$3 \mu \mathrm{M}$<smiles>COC(=O)Cc1c(O)cc(Br)c(O)c1Br</smiles>

53

$1.8 \mu \mathrm{M}$

$12.0 \mu \mathrm{M}$

Figure 22. Structures of marine sponge compounds as inhibitors of Pfnek-1. PfFCB1: Plasmodium falciparum FCB1 strain.

\section{Phosphoinositide Lipid Kinases (PIKs)}

Five P. falciparum PIKs have been identified that are phylogenetically divergent from human PIKs [144]. The phosphoinositide 3-kinase (PfPI3K) and phosphatidylinositol 4-kinase (PfPI4K) homologues are both essential for parasite survival and most likely involved in cellular signalling and trafficking [145-147].

\subsection{PIK Inhibitor Development}

\subsubsection{PI3K}

To date, only two compounds have been identified for studying the functions of PfPI3K. The mammalian PI3K inhibitors (Figure 23) wortmannin (54) and LY294002 (55) both inhibit PfPI3K and blood-stage P. falciparum parasite growth [146,147]. PfPI3K was also identified as a target of dihydroartemisinin (56, Figure 23) during the early ring stages [148].<smiles>COC[C@H]1OC(=O)c2coc3c2C1(C)C1=C(C3=O)[C@]2(C)CCC(=O)[C@@]2(C)C[C@H]1OC(C)=O</smiles>

54<smiles>O=c1cc(N2CCOCC2)oc2c(-c3ccccc3)cccc12</smiles>

55

$$
1.8 \mu \mathrm{M}
$$$$
26.0 \mu \mathrm{M}
$$

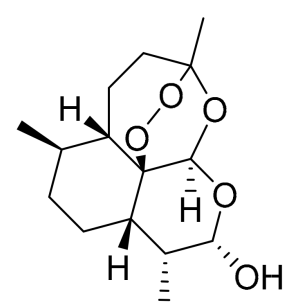

56

$4 \mathrm{nM}$

$3 \mathrm{nM}$

Figure 23. Structures of wortmannin, LY294002 and dihydroartemisinin.

\subsubsection{PI4K}

Considerable progress has been made with regards to inhibitor development for PI4K, with one candidate progressing into clinical trial evaluation. The imidazopyridine/ pyrazine/ pyridazine class [145,149-152], the aminopyridine/pyrazine class [153-156] and the bipyridine sulfonamide [157] scaffolds have been evaluated for PI4K inhibition. 
A phenotypic screening identified compound 57 (Figure 24), which demonstrated activity against $P$. falciparum blood-stage parasites but was inactive against $P$. yoelii $(P y)$ and $P$. cynomolgi $(P c)$ liver-stage parasites [152]. Liver-stage activity was acquired by replacing the imidazopyridine core of compound 57 with an imidazopyrazine core (KAI407, 58, Figure 24). From a series of imidazopyrazines, compound 59 (KDU691, Figure 24) had optimal antimalarial activity (blood and liver stages) and physicochemical properties, which translated into in vivo efficacy against $P$. berghei-infected mice [152]. McNamara and co-workers [145] further demonstrated that compound 59 reduced liver- and blood-stage parasites, gametocyte viability and transmission to the mosquito vector for multiple Plasmodium species. Plasmodial PI4K was identified as the direct target of imidazopyrazine compounds [145].

Le Manach and co-workers [150] synthesised a series of imidazopyrazines based on structures of hits identified during a screening campaign. Compound 61 (Figure 24) was highly active against drug-sensitive (NF54) and -resistant (K1) P. falciparum strains and reduced parasitemia by $98 \%$ in $P$. berghei-infected mice $(4 \times 50 \mathrm{mg} / \mathrm{kg})$. However, compound $\mathbf{6 1}$ failed to produce significant in vivo efficacy at lower doses, displayed poor solubility and showed activity towards hERG. Further optimisation of this scaffold led to compound 62 (Figure 24), which was completely curative in P. berghei-infected mice $(4 \times 50 \mathrm{mg} / \mathrm{kg})$ and retained high in vivo efficacy at lower doses [151]. Compound 62 acted as a prodrug which was rapidly metabolised to the highly active sulfone (compound 63, Figure 24) in vivo.

Compound 64 (Figure 25) was identified during a high-throughput screening campaign against drug-sensitive (NF54) and -resistant (K1) P. falciparum strains [155]. Optimisation of the 2-aminopyridine scaffold resulted in compound 65 (MMV390048 or MMV048, Figure 25), which demonstrated in vitro and in vivo activity against the liver, blood and sexual (gametocyte) stages of the parasite [155,158]. Whole-genome screening of MMV048-resistant $P$. falciparum strains and chemoproteomic profiling identified plasmodial PI4K as the target of MMV048 [158]. MMV048 showed high selectivity over human and other plasmodial kinases, a good ADME profile and an acceptable preclinical safety profile in various animal species (mice, rats, dogs and monkeys) $[155,158]$. Phase I clinical trials for MMV048 were recently completed (ClinicalTrials.gov: NCT02230579; NCT02281344; NCT02554799) [159]. A single oral dose of up to $120 \mathrm{mg}$ was generally well tolerated in healthy volunteers and adverse events were mild to moderate. Treatment with $20 \mathrm{mg}$ of MMV048 initially reduced parasitemia in volunteers with induced P. falciparum blood-stage malaria; however, recrudescence occurred 2 to 7 days after treatment. Formulation influences the pharmacodynamic profile of MMV048, with the tablet formulation resulting in significantly less variability than the powder-in-a-bottle formulation. MMV048 progressed to phase 2a clinical trials in 2017, where its activity was evaluated in Ethiopian adults with either uncomplicated P. falciparum or P. vivax infection (ClinicalTrials.gov: NCT02880241). 

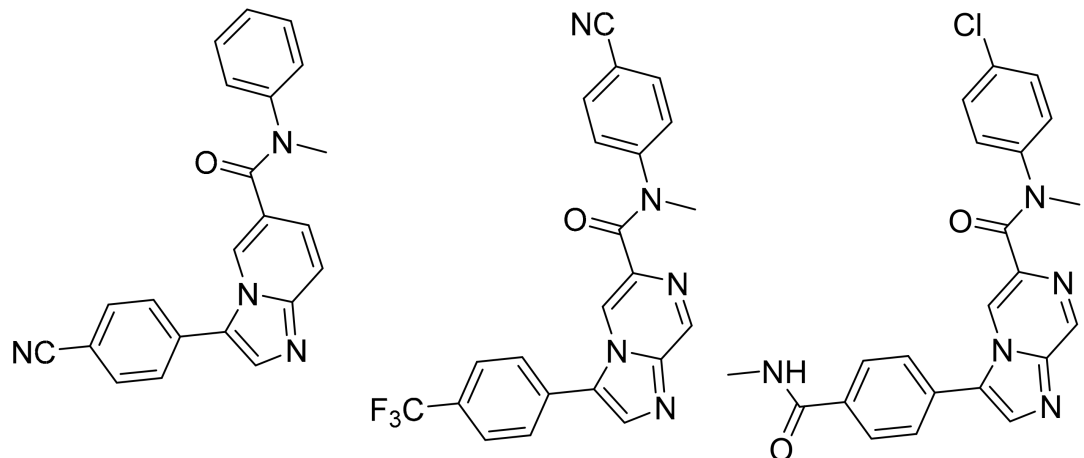

58

$0.60 \mu \mathrm{M}$

$>10 \mu \mathrm{M}$

$>10 \mu \mathrm{M}$

ND

ND

In vivo $\mathrm{Pb}$ mouse model

(\% parasitemia reduction,

oral dose)

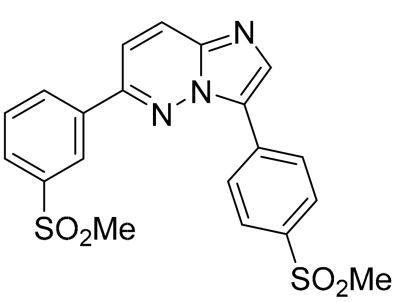

$7.3 \mathrm{nM}$

$6.3 \mathrm{nM}$

$98 \%$

$50 \mathrm{mg} / \mathrm{kg}$

Once daily, 4 days

PfNF54 blood stage EC50

PfK1 blood stage EC50

In vivo $\mathrm{Pb}$ mouse model

oral dose)

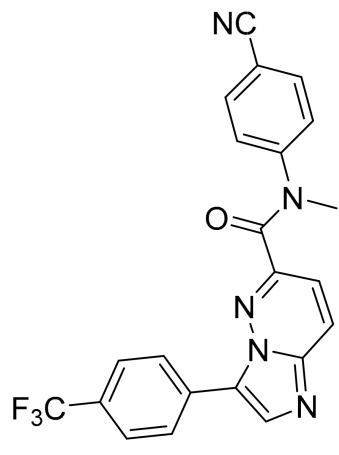

60

$0.004 \mu \mathrm{M}$

$0.009 \mu \mathrm{M}$

ND

ND

ND

Figure 24. Imidazopyridine-, pyrazine- and pyridazine-based compounds as inhibitors of plasmodial PI4K. 


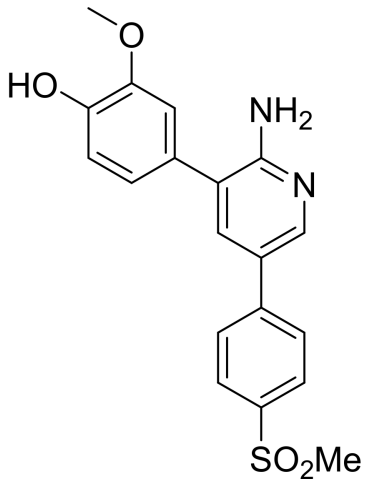

64

PvPI4K IC 50

PfNF54 blood stage EC50

PfK1 blood stage EC50

In vivo $P b$ mouse model

ED90

In vivo $P f$ mouse model

ED90

ND

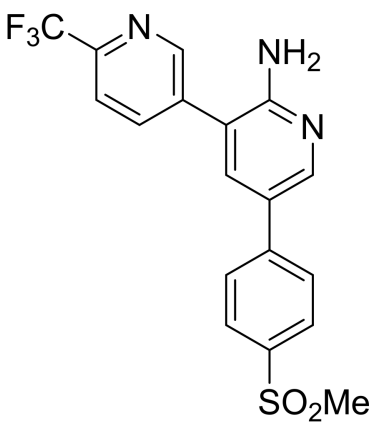

$3.4 \mathrm{nM}$

$28 \mathrm{nM}$

$25 \mathrm{nM}$

$1.1 \mathrm{mg} / \mathrm{kg}$

$0.57 \mathrm{mg} / \mathrm{kg}$

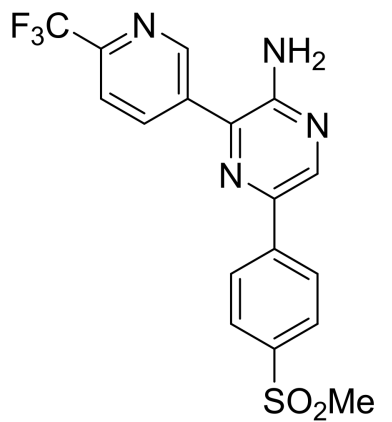

66

$\begin{array}{cc}1.5 \mathrm{nM} & 23 \mathrm{nM} \\ 10.0 \mathrm{nM} & 5.4 \mathrm{nM} \\ 8.4 \mathrm{nM} & 5.2 \mathrm{nM}\end{array}$

ND

$1.0 \mathrm{mg} / \mathrm{kg}$
$2 \mathrm{nM}$

$0.12 \mathrm{mg} / \mathrm{kg}$

$0.25 \mathrm{mg} / \mathrm{kg}$

Figure 25. Structures and biological data of aminopyridine- and pyrazine-based compounds as inhibitors of plasmodial PI4K 
Younis and co-workers [156] replaced the 2-aminopyridine core of MMV048 with a 2-aminopyrazine ring (compound 66, Figure 25), which improved the in vitro antimalarial activity but had poor solubility. In an attempt to improve the aqueous solubility, the methyl sulfonyl group of compound 66 was replaced with a piperazinyl carboxamide (UCT943, 67, Figure 25) [154]. While retaining PI4K selectivity, UCT943 demonstrated improved solubility and potency against all life cycle stages compared to the clinical candidate, MMV048 [154,160]. The in vivo efficacy of UCT943 in a P. falciparum-infected NSG mouse model was also 2-fold more potent than that of MMV048 [160]. Gibhard and co-workers [153] also explored the option of using the more soluble sulfoxide analogue of compound $\mathbf{6 6}$ as a prodrug to improve drug exposure in vivo. In a P. falciparum-infected NSG mouse model, the sulfoxide was rapidly absorbed and converted to its sulfone analogue (compound 66), which resulted in higher exposure compared to when the sulfone was administered.

Hit compound 68 (Figure 26), discovered during a phenotypic screening campaign, displayed weak in vitro activity against $P$. falciparum blood-stage parasites $\left(\mathrm{EC}_{50}: 3.9 \mu \mathrm{M}\right)$ but had potent PfPI4K activity $\left(\mathrm{IC}_{50}: 7.7 \mathrm{nM}\right)$ [157]. Systematic optimisation of the bipyridine sulfonamide scaffold led to compound 69 (Figure 26) which was selective for PfPI4K and had potent activity against several drug-sensitive and -resistant $P$. falciparum strains. Compound 69 showed in vivo blood-stage efficacy (99.9\% reduction in parasitemia at $80 \mathrm{mg} / \mathrm{kg}$ for 7 days) in a $P$. yoelii-infected mouse model and liver-stage efficacy $(1 \mathrm{mg} / \mathrm{kg}$, single dose) in a P. berghei-infected mouse model.<smiles>O=S(=O)(Nc1cc(-c2cnc3[nH]ccc3c2)cnc1Cl)c1ccccc1</smiles>

68

PfPI4K IC50

Pf3D7 IC50

In vivo blood stage efficacy

Py mouse model

(\% parasitemia reduction, oral dose)

In vivo liver stage efficacy

$\mathrm{Pb}$ sporozoite-infected mice

(Full protection and cure, oral dose)<smiles>CNC(=O)c1cncc(-c2cnc(Cl)c(NS(=O)(=O)c3ccccc3)c2)c1</smiles>

69

$0.9 \mathrm{nM}$

$25.1 \mathrm{nM}$

$99.9 \%$

$80 \mathrm{mg} / \mathrm{kg}$

Once daily, 7 days

$1 \mathrm{mg} / \mathrm{kg}$

Single dose

Figure 26. Bipyridine sulfonamide based compounds as inhibitors of PfPI4K.

In silico screening campaigns against PfPI4K homology models have identified a number of virtual hits that can be used as potential starting points for drug development [149,161,162]. Compounds 70-74 (Figure 27) all have good ADMET properties and form strong interactions with the ATP-binding site of PfPI4K. Compounds $\mathbf{7 1}$ and $\mathbf{7 2}$ also demonstrated selectivity for PfPI4K over the human PI4KB orthologue [149]. 


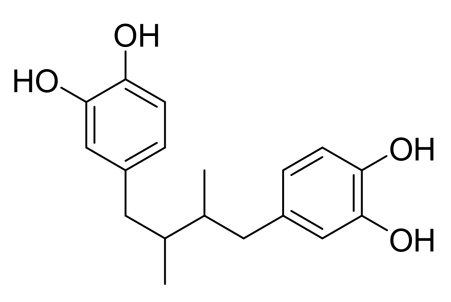

70

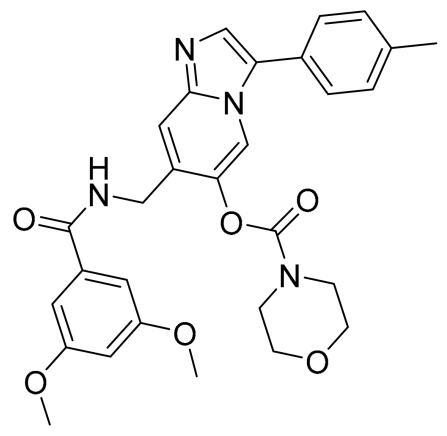

73

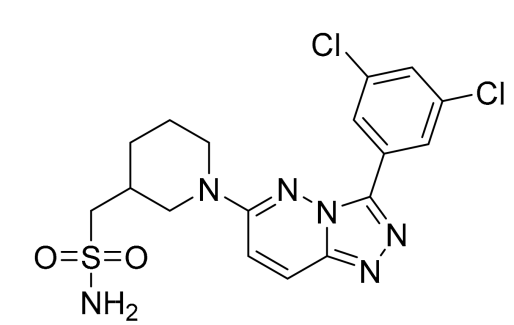

71

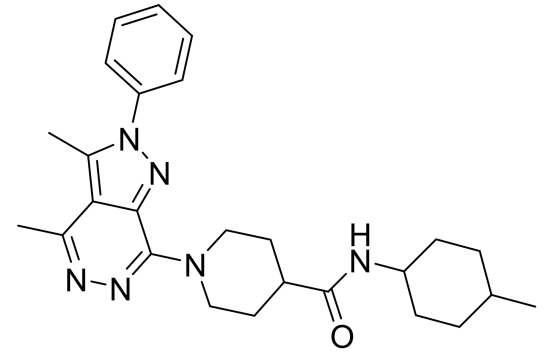

72

Figure 27. Hits identified during in silico screening against $P f$ PI4K homology models. 


\section{Orphan Kinases}

Orphan kinases are particularly attractive drug targets as they do not have orthologues in the human host [11]. Some of the orphan kinases that have been characterised for P. falciparum include protein kinase 7 (PfPK7), protein kinase 9 (PfPK9) and the FIKK family [163].

PfPK7 is a composite kinase that displays homology to the mitogen-activated protein kinase (MAPKK) family in its C-terminal region and fungal PKA homology in its N-terminal region [164]. Despite its homology, PfPK7 is unlikely to be a functional MAPKK orthologue as the typical MAPKK activation site is absent and it is unable to phosphorylate the two MAPK orthologues ( $P f$ map-1 and Pfmap-2) in vitro [164]. PfPK7 is expressed in asexual liver- and blood-stage parasites as well as in gametocytes and is localised in the cytoplasm [164]. Disruption of the $p f p k 7$ gene decreases the growth rate of erythrocytic parasites and drastically reduces the parasite's ability to produce oocysts during the sexual stage [165].

PfPK9 clusters at the base of the CDPK and AGC family branches but does not associate with either of the two groups [13]. PfPK9 is essential for P. falciparum parasite viability [22,166] and is expressed during the late ring stages as well as the schizont stage where it exhibits maximal expression [167]. During the ring stages, PfPK9 is localised to the parasitophorous vacuolar membrane, which acts as the interface between the parasite and the cytoplasm of the erythrocyte. As the parasite matures into schizonts, the localisation of PfPK9 shifts to the parasite's plasma membrane [167]. This suggests that PfPK9 is involved in signal transduction between the cytosol of the parasite and the intraerythrocytic environment. Thus far, only one downstream target has been identified for PfPK9, namely E2 ubiquitin-conjugating enzyme 13 (PfUBC13) [167]. PfUBC13 is an orthologue of eukaryotic UBC13 which is involved in the attachment of lysine 63 (K63)-linked polyubiquitin chains to target proteins. This modulates the activity of various cellular processes such as DNA repair and immune responses.

The FIKK family, a group of serine/threonine kinases specific to apicomplexan parasites, is named after the phenylalanine (F)-isoleucine (I)-lysine (K)-lysine (K) motif located in the $N$-terminal region of their kinase domains. While most Plasmodium species only have a single FIKK kinase, 20 FIKK kinase members have been identified for P. falciparum [168]. Although the biological functions of this group of kinases are still unclear, evidence suggests that most FIKK kinases are involved in erythrocyte remodelling during infection $[169,170]$. Studies have identified nine FIKK kinases that are exported via the Maurer's clefts to the erythrocytic membrane, where remodelling occurs [169,171]. Disruption of individual genes encoding for PfFIKK4.2, PfFIKK7.1 or PfFIKK12 significantly altered erythrocytic membrane rigidity and phosphorylation of certain cytoskeletal membrane proteins $[170,172]$. One such erythrocytic cytoskeletal protein, dematin, was also identified as a potential substrate for PfFIKK4.1 [173].

\subsection{Inhibitor Development for Orphan Kinases}

\subsubsection{PfPK7}

As PfPK7 plays a role in both the erythrocytic and sexual stages, PfPK7 inhibitors could possibly decrease parasite virulence and act as transmission-blocking agents. This possibility makes PfPK7 an interesting target for drug development. A number of established kinase inhibitors, including a MAPKK inhibitor (U0126) and PKA inhibitors (H89 \& PKI), had no activity against recombinant PfPK7 $\left(\mathrm{IC}_{50}>100 \mu \mathrm{M}\right)$ [164]. A high-throughput screening campaign identified imidazopyridines (compounds 75 and 76, Figure 28) and pyrazolopyrimidine (compound 77, Figure 28) with PfPK7 and in vitro activity in the low micromolar range [174]. However, these compounds also inhibited a number of other kinases in the low micromolar range. 
<smiles>CC(C)C(CO)Nc1ccc2ncc(-c3ccc(C#N)cc3)n2n1</smiles>

75<smiles>N#Cc1ccc(-c2cnc3ccc(NC4CCOCC4)nn23)cc1</smiles>

76<smiles>Clc1ccc(-c2cnn3ccc(NCc4cccnc4)nc23)cc1</smiles>

77

$4.6 \mu \mathrm{M}$

$1.0 \mu \mathrm{M}$

Pf blood stage GI $I_{50}$

$2.5 \mu \mathrm{M}$

$1.5 \mu \mathrm{M}$

Figure 28. Imidazopyridine- and pyrazolopyrimidine-based compounds as inhibitors of PfPK7.

The crystal structures of PfPK7 in complex with adenylylimidodiphosphate (an ATP analogue, PBD: 2PML), compound 75 (PBD: 2PMN) and hymenialdisine (PBD: 2PMO) were elucidated. These structures highlighted some atypical features that are specifically relevant to drug discovery: Firstly, an aspartic acid residue (D123) in the hinge region protrudes to block access to the C-terminal domain surface in the ATP-binding site (Figure 29A). This structural impediment explains the inactivity of most established protein kinase inhibitors towards PfPK7. Secondly, a hydrophobic pocket was identified in the back of the ATP-binding site, which can be exploited for designing PfPK7-selective drugs (Figure 29B).
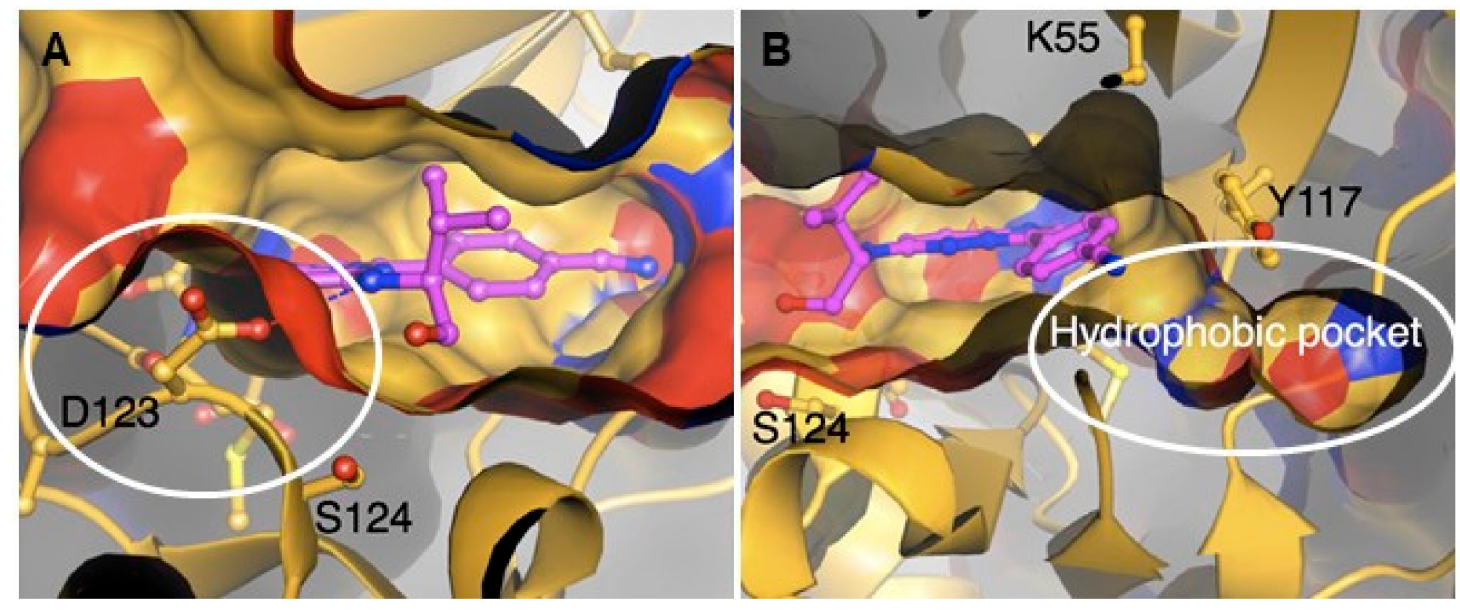

Figure 29. Structure of $P f \mathrm{PK} 7$ in complex with compound 75. (A) The protruding aspartic acid residue (D123) blocks access to the C-terminal domain surface of the ATP-binding site. (B) The hydrophobic pocket located at the back of the ATP-binding site. (Figure reproduced from [174] with permission from Elsevier.)

Another high-throughput screening campaign identified a number of imidazopyridazines (e.g., 78, Figure 30) as weak PfPK7 inhibitors [175]. Using the crystal structure data from the previous study [174], Bouloc and co-workers [175] aimed to improve the potency of the imidazopyridazine scaffold by varying the aryl and amine substituents of 78. This ultimately led to compounds $\mathbf{7 9}$ and $\mathbf{8 0}$ which demonstrated improved PfPK7 activity ( $\mathrm{IC}_{50}: 0.28 \mu \mathrm{M}$ and $0.13 \mu \mathrm{M}$, respectively). These compounds also showed antiplasmodial activity against drug-sensitive (3D7) and -resistant (K1) strains of P. falciparum without significant cytotoxicity. However, these compounds were also unselective and inhibited several other kinases. 


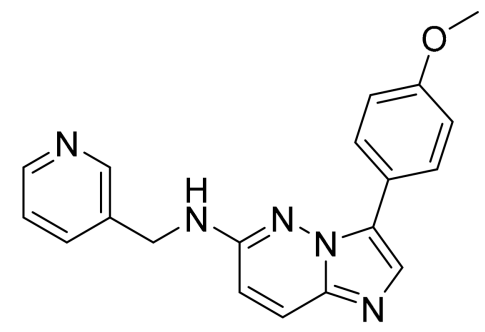

78

PfPK7 IC50

Pf3D7 blood stage EC50

PfK1 blood stage $\mathrm{EC}_{50}$

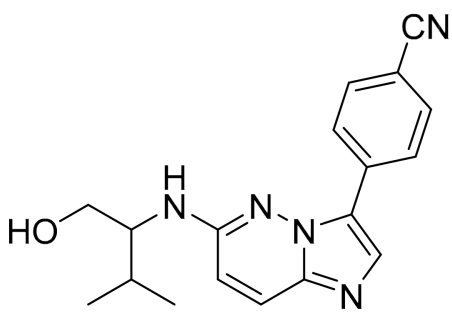

79

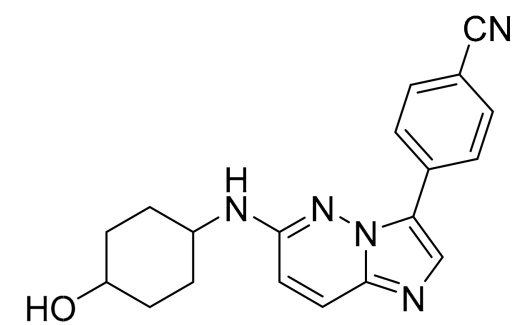

80

$0.13 \mu \mathrm{M}$

$1.03 \mu \mathrm{M}$

$2.65 \mu \mathrm{M}$

Figure 30. Imidazopyridazine-based compounds as inhibitors of PfPK7. 
Klein and co-workers [176] aimed to design PfPK7 inhibitors that exploit the hydrophobic pocket in the ATP-binding site. They designed two series of pyrazolopyrimidines with 1- and 4-substituted triazole rings at the 3-position of the pyrazole ring. The substituted triazoles were designed with a "bent" geometry that would allow the inhibitor to interact with the hydrophobic pocket. Two compounds (81 and 82, Figure 31) demonstrated PfPK7 activity in micromolar concentrations ( $\mathrm{IC}_{50}: 20$ and $10 \mu \mathrm{M}$, respectively). Docking studies with compound $\mathbf{8 1}$ indicated binding interactions similar to those seen with the ATP analogue but with additional interaction of the 4-phenyl-(1,2,3-triazol-1-yl) moiety with the hydrophobic pocket.

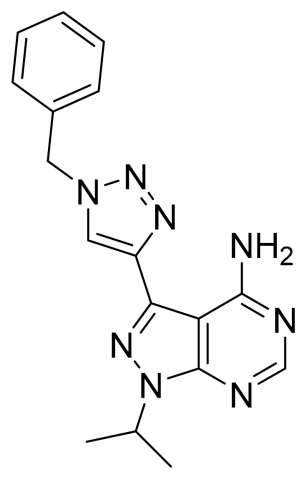

81

PfPK7 IC50

$20 \mu \mathrm{M}$

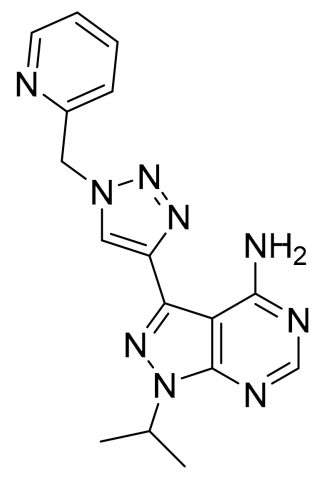

82

$10 \mu \mathrm{M}$

Figure 31. Structures of pyrazolopyrimidine-based compounds with a bent geometry.

\subsubsection{PfPK9}

Only one study has been published thus far with regards to inhibitor development for PfPK9. Screening of a kinase-targeted library against PfPK9 identified takinib (83, Figure 32), which demonstrated low micromolar binding affinity $\left(\mathrm{K}_{\mathrm{d}(\mathrm{app})}\right.$ : $\left.0.46 \mu \mathrm{M}\right)$ for PfPK9 [177]. Takinib is a potent inhibitor $\left(\mathrm{IC}_{50}: 9.5 \mathrm{nM},[178]\right)$ of human mitogen-activated protein kinase kinase kinase 7 (MAP3K7, or more commonly referred to as TAK1). TAK1's activity is regulated through K63-ubiquitination by human ubiquitin-conjugating enzyme, UBC13 [179]. Treatment of P. falciparum-infected erythrocytes with takinib resulted in a dose-dependent reduction in K63-ubiquitin levels, confirming that PfPK9 regulates the activity of PfUBC13 in vivo [167]. In order to achieve PfPK9 selectivity over TAK1, a series of takinib analogues was developed. From this series, compound $\mathbf{8 4}$ (Figure 32) was identified as a PfPK9-selective inhibitor $\left(\mathrm{K}_{\mathrm{d}(\mathrm{app})}: 4.1 \mu \mathrm{M}, 8.9\right.$-fold less potent than takinib) with antiparasitic activity against liver-stage P. berghei parasites $\left(\mathrm{EC}_{50}=43 \mu \mathrm{M}\right)$ and no significant hepatocyte cytotoxicity. Compound 84 also showed a similar decrease in K63-linked ubiquitin levels in $P$. falciparum-infected erythrocytes, as seen with takinib. Interestingly, takinib and compound 84 both induced an unusual phenotype in liver-stage parasites. Liver-stage drugs generally decrease the size and/or number of parasites. However, when liver-stage $P$. berghei parasites were treated with $10 \mu \mathrm{M}$ of either takinib or compound 84, the parasite size increased while the number of parasites remained unchanged. Treatment with $30 \mu \mathrm{M}$ of either takinib or compound $\mathbf{8 4}$ also increased the parasite size but simultaneously decreased the number of parasites. This suggests a unique mechanism of action for these inhibitors, which has potential in new antimalarial drug development. 


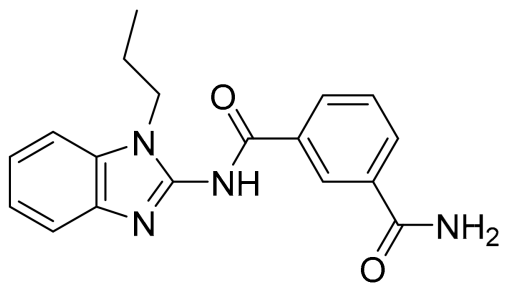

83

PfPK9 Kd(app)

TAK1 IC50

$\mathrm{Pb}$ liver stage $\mathrm{EC}_{50}$
$0.5 \mu \mathrm{M}$

$9.5 \mu \mathrm{M}$

$7.3 \mu \mathrm{M}$<smiles>CCn1c(NC(=O)c2cccc(C(=O)O)c2)nc2ccccc21</smiles>

84

$4 \mu \mathrm{M}$

$120 \mu \mathrm{M}$

$43 \mu \mathrm{M}$

Figure 32. Structures and biological data of takinib and its analogue. $\mathrm{K}_{\mathrm{D}(\mathrm{app})}$ : apparent dissociation constant.

\subsubsection{FIKKs}

To date, five P. falciparum FIKK kinase members have been identified as essential for parasite survival, three of which are exported to the erythrocytic membrane (PfFIKK9.1, PfFIKK10.1 and PfFIKK10.2) and two of which are localised within the parasite (PfFIKK3 and PfFIKK9.5) [171]. The non-exported FIKK8 kinase was also demonstrated to be essential to P. berghei erythrocytic parasites [180]. FIKK8 is the only FIKK kinase member that is conserved in all Plasmodium species as well as other apicomplexan parasites [181].

Interestingly, FIKK kinases tend to have small gatekeeper residues [180,182], a characteristic that is rarely seen in human serine/threonine kinases but is more common to human tyrosine kinases [183]. Not surprisingly, a screening campaign identified a number of tyrosine kinase inhibitors that block FIKK kinase activity [182,184]. One such tyrosine inhibitor, an anthraquinone named emodin (85, Figure 33), demonstrated in vitro activity against various $P$. falciparum strains $\left(\mathrm{IC}_{50}\right.$ values of approximately $13 \mu \mathrm{M})[185]$ as well as activity against PfFIKK8 $\left(\mathrm{IC}_{50}: 2 \mu \mathrm{M}\right)$ and the P. vivax orthologue (PvFIKK8; $\mathrm{IC}_{50}: 1.9 \mu \mathrm{M}$ ) [182,184]. Structurally related analogues of emodin (Figure 33), aloe emodin (86) and rufigallol (87), did not demonstrate any significant activity against PfFIKK8 [184].<smiles>Cc1cc(O)c2c(c1)C(=O)c1cc(O)cc(O)c1C2=O</smiles>

85<smiles>O=C1c2cc(O)c(O)c(O)c2C(=O)c2cc(O)c(O)c(O)c21</smiles>

86

No inhibition

ND<smiles>O=C1c2ccc(O)cc2C(=O)c2c(O)cc(CO)cc21</smiles>

87

No inhibition

ND

Figure 33. Structures of emodin, aloe emodin and rufigallol.

\section{Summary}

Recurring antimalarial drug resistance necessitates the development of new antimalarial drugs with different chemical scaffolds and modes of action. Plasmodial kinases were identified as promising 
targets for next-generation antimalarial drug development. To date, significant progress has been made towards characterisation and small-molecule inhibitor development for plasmodial kinases. Various plasmodial kinases have been validated as essential for one or multiple stages of the parasite's life cycle. Therefore, targeting plasmodial kinases could result in new drugs for chemoprevention and transmission-blocking, which will contribute to malaria elimination.

Plasmodial kinase inhibitors have been successfully identified by means of phenotypic and target-based screening approaches. The expression of several plasmodial kinases as active recombinant enzymes has facilitated crystallography and target-based medicinal chemistry efforts. Knowledge gained from developing human kinase inhibitors has also significantly contributed to plasmodial kinase inhibitor development. A number of potential scaffolds were identified through either phenotypic or target-based screening of human kinase inhibitor libraries.

Inhibitor promiscuity is always a concern when dealing with a conserved group of targets such as the kinases. Therefore, it is important to cross-screen potential plasmodial kinase inhibitors against human kinase panels. Inhibitors that target multiple plasmodial kinases could be beneficial as this ability would limit the risk of drug resistance, provided that this promiscuity does not also affect host kinases. Overall, studies targeting plasmodial kinases have demonstrated that selectivity over host kinases is an achievable goal.

Although a significant amount of work still needs to be done in terms of fully understanding the functions, stage specificity and interactions of plasmodial kinases, this group shows promise for future antimalarial drug development.

Author Contributions: Conceptualization, L.J.L.; writing—original draft preparation, C.M.; writing-review and editing, R.v.d.S., R.M.B. and L.J.L. All authors have read and agreed to the published version of the manuscript.

Funding: This research received no external funding.

Conflicts of Interest: The authors declare no conflict of interest.

\section{References}

1. WHO. World Malaria Report. 2019. Available online: https://www.who.int/malaria/publications/world_ malaria_report/en/ (accessed on 17 February 2020).

2. WHO. The Potential Impact of Health Service Disruption on the Burden of Malaria: A Modelling Analysis for Countries in Sub-Saharan Africa. Available online: https:/www.who.int/publications/i/item/the-potentialimpact-of-health-service-disruptions-on-the-burden-of-malaria (accessed on 1 September 2020).

3. Nghochuzie, N.N.; Olwal, C.O.; Udoakang, A.J.; Amenga-Etego, L.N.; Amambua-Ngwa, A. Pausing the Fight Against Malaria to Combat the COVID-19 Pandemic in Africa: Is the Future of Malaria Bleak? Front. Microbiol. 2020, 11. [CrossRef]

4. WHO. Status Report on Artemisinin Resistance and Artemisinin-Based Combination Therapy Efficacy. Available online: https://www.who.int/malaria/areas/drug_resistance/updates/en/ (accessed on 12 February 2020).

5. Noisang, C.; Prosser, C.; Meyer, W.; Chemoh, W.; Ellis, J.; Sawangjaroen, N.; Lee, R. Molecular detection of drug resistant malaria in Southern Thailand. Malar J. 2019, 18. [CrossRef]

6. Yadav, D.K.; Kumar, S.; Teli, M.K.; Yadav, R.; Chaudhary, S. Molecular Targets for Malarial Chemotherapy: A Review. Curr. Top. Med. Chem. 2019, 19, 861-873. [CrossRef] [PubMed]

7. Rout, S.; Mahapatra, R.K. Plasmodium falciparum: Multidrug resistance. Chem. Biol. Drug Des. 2019, 93, 737-759. [CrossRef] [PubMed]

8. $\quad$ Burrows, J.N.; Duparc, S.; Gutteridge, W.E.; Hooft van Huijsduijnen, R.; Kaszubska, W.; Macintyre, F.; Mazzuri, S.; Mohrle, J.J.; Wells, T.N.C. New developments in anti-malarial target candidate and product profiles. Malar. J. 2017, 16. [CrossRef]

9. Doerig, C. Protein kinases as targets for anti-parasitic chemotherapy. Biochim. Biophys. Acta 2004, 1697, 155-168. [CrossRef] 
10. Doerig, C.; Abdi, A.; Bland, N.; Eschenlauer, S.; Dorin-Semblat, D.; Fennell, C.; Halbert, J.; Holland, Z.; Nivez, M.P.; Semblat, J.P.; et al. Malaria: Targeting parasite and host cell kinomes. Biochim. Biophys. Acta 2010, 1804, 604-612. [CrossRef]

11. Doerig, C.; Meijer, L. Antimalarial drug discovery: Targeting protein kinases. Expert. Opin. Targets 2007, 11, 279-290. [CrossRef]

12. Srinivasan, A.N.; Krupa, A. A genomic perspective of protein kinases in Plasmodium falciparum. Proteins 2005, 58, 180-189. [CrossRef]

13. Ward, P.; Equinet, L.; Packer, J.; Doerig, C. Protein kinases of the human malaria parasite Plasmodium falciparum: The kinome of a divergent eukaryote. Bmc Genom. 2004, 5. [CrossRef]

14. Cabrera, D.G.; Horatscheck, A.; Wilson, C.R.; Basarab, G.; Eyermann, C.J.; Chibale, K. Plasmodial kinase inhibitors: License to cure? J. Med. Chem. 2018, 61, 8061-8077. [CrossRef] [PubMed]

15. Billker, O.; Lourido, S.; Sibley, L.D. Calcium-dependent signaling and kinases in apicomplexan parasites. Cell Host Microbe 2009, 5, 612-622. [CrossRef]

16. Ghartey-Kwansah, G.; Yin, Q.; Li, Z.; Gumpper, K.; Sun, Y.; Yang, R.; Wang, D.; Jones, O.; Zhou, X.; Wang, L.; et al. Calcium-dependent Protein Kinases in Malaria Parasite Development and Infection. Cell Transpl. 2020, 29. [CrossRef]

17. Hui, R.; El Bakkouri, M.; Sibley, L.D. Designing selective inhibitors for calcium-dependent protein kinases in apicomplexans. Trends Pharm. Sci. 2015, 36, 452-460. [CrossRef]

18. Green, J.L.; Rees-Channer, R.R.; Howell, S.A.; Martin, S.R.; Knuepfer, E.; Taylor, H.M.; Grainger, M.; Holder, A.A. The motor complex of Plasmodium falciparum: Phosphorylation by a calcium-dependent protein kinase. J. Biol. Chem. 2008, 283. [CrossRef] [PubMed]

19. Kato, N.; Sakata, T.; Breton, G.; Le Roch, K.G.; Nagle, A.; Andersen, C.; Bursulaya, B.; Henson, K.; Johnson, J.; Kumar, K.A.; et al. Gene expression signatures and small-molecule compounds link a protein kinase to Plasmodium falciparum motility. Nat. Chem. Biol. 2008, 4, 347-356. [CrossRef] [PubMed]

20. Bansal, A.; Singh, S.; More, K.R.; Hans, D.; Nangalia, K.; Yogavel, M.; Sharma, A.; Chitnis, C.E. Characterization of Plasmodium falciparum calcium-dependent protein kinase 1 (PfCDPK1) and its role in microneme secretion during erythrocyte invasion. J. Biol. Chem. 2013, 288, 1590-1602. [CrossRef]

21. Bansal, A.; Molina-Cruz, A.; Brzostowski, J.; Liu, P.; Luo, Y.; Gunalan, K.; Li, Y.; Ribeiro, J.M.C.; Miller, L.H. PfCDPK1 is critical for malaria parasite gametogenesis and mosquito infection. Proc. Natl. Acad. Sci. USA 2018, 115, 774-779. [CrossRef]

22. Solyakov, L.; Halbert, J.; Alam, M.M.; Semblat, J.P.; Dorin-Semblat, D.; Reininger, L.; Bottrill, A.R.; Mistry, S.; Abdi, A.; Fennell, C.; et al. Global kinomic and phospho-proteomic analyses of the human malaria parasite Plasmodium falciparum. Nat. Commun. 2011, 2, 1-12. [CrossRef]

23. Green, J.L.; Moon, R.W.; Whalley, D.; Bowyer, P.W.; Wallace, C.; Rochani, A.; Nageshan, R.K.; Howell, S.A.; Grainger, M.; Jones, H.M.; et al. Imidazopyridazine Inhibitors of Plasmodium falciparum Calcium-Dependent Protein Kinase 1 Also Target Cyclic GMP-Dependent Protein Kinase and Heat Shock Protein 90 to Kill the Parasite at Different Stages of Intracellular Development. Antimicrob. Agents Chemother. 2015, 60, 1464-1475. [CrossRef]

24. Kumar, S.; Kumar, M.; Ekka, R.; Dvorin, J.D.; Paul, A.S.; Madugundu, A.K.; Gilberger, T.; Gowda, H.; Duraisingh, M.T.; Keshava Prasad, T.S.; et al. PfCDPK1 mediated signaling in erythrocytic stages of Plasmodium falciparum. Nat. Commun. 2017, 8. [CrossRef]

25. Sebastian, S.; Brochet, M.; Collins, M.O.; Schwach, F.; Jones, M.L.; Goulding, D.; Rayner, J.C.; Choudhary, J.S.; Billker, O. A Plasmodium calcium-dependent protein kinase controls zygote development and transmission by translationally activating repressed mRNAs. Cell Host Microbe 2012, 12, 9-19. [CrossRef]

26. Bansal, A.; Molina-Cruz, A.; Brzostowski, J.; Mu, J.; Miller, L.H. Plasmodium falciparum Calcium-Dependent Protein Kinase 2 Is Critical for Male Gametocyte Exflagellation but Not Essential for Asexual Proliferation. mBio 2017, 8. [CrossRef]

27. Kato, K.; Sudo, A.; Kobayashi, K.; Sugi, T.; Tohya, Y.; Akashi, H. Characterization of Plasmodium falciparum calcium-dependent protein kinase 4. Parasitol. Int. 2009, 58, 394-400. [CrossRef]

28. Li, J.; Baker, D.A.; Cox, L.S. Sexual stage-specific expression of a third calcium-dependent protein kinase from Plasmodium falciparum. Biochim. Biophys. Acta 2000, 1491, 341-349. [CrossRef] 
29. Govindasamy, K.; Jebiwott, S.; Jaijyan, D.K.; Davidow, A.; Ojo, K.K.; Van Voorhis, W.C.; Brochet, M.; Billker, O.; Bhanot, P. Invasion of hepatocytes by Plasmodium sporozoites requires cGMP-dependent protein kinase and calcium dependent protein kinase 4. Mol. Microbiol. 2016, 102, 349-363. [CrossRef]

30. Ishino, T.; Orito, Y.; Chinzei, Y.; Yuda, M. A calcium-dependent protein kinase regulates Plasmodium ookinete access to the midgut epithelial cell. Mol. Microbiol. 2006, 59, 1175-1184. [CrossRef]

31. Siden-Kiamos, I.; Ecker, A.; Nyback, S.; Louis, C.; Sinden, R.E.; Billker, O. Plasmodium berghei calcium-dependent protein kinase 3 is required for ookinete gliding motility and mosquito midgut invasion. Mol. Microbiol. 2006, 60, 1355-1363. [CrossRef]

32. Absalon, S.; Blomqvist, K.; Rudlaff, R.M.; DeLano, T.J.; Pollastri, M.P.; Dvorin, J.D. Calcium-dependent protein kinase 5 is required for release of egress-specific organelles in Plasmodium falciparum. mBio 2018, 9. [CrossRef]

33. Dvorin, J.D.; Martyn, D.C.; Patel, S.D.; Grimley, J.S.; Collins, C.R.; Hopp, C.S.; Bright, A.T.; Westenberger, S.; Winzeler, E.; Blackman, M.J.; et al. A plant-like kinase in Plasmodium falciparum regulates parasite egress from erythrocytes. Science 2010, 328, 910-912. [CrossRef]

34. Kumar, P.; Tripathi, A.; Ranjan, R.; Halbert, J.; Gilberger, T.; Doerig, C.; Sharma, P. Regulation of Plasmodium falciparum development by calcium-dependent protein kinase 7 (PfCDPK7). J. Biol. Chem. 2014, 289. [CrossRef]

35. Coppi, A.; Tewari, R.; Bishop, J.R.; Bennett, B.L.; Lawrence, R.; Esko, J.D.; Billker, O.; Sinnis, P. Heparan sulfate proteoglycans provide a signal to Plasmodium sporozoites to stop migrating and productively invade cells. Cell Host Microbe 2007, 2, 316-327. [CrossRef] [PubMed]

36. Van Voorhis, W.C.; Doggett, J.S.; Parsons, M.; Hulverson, M.A.; Choi, R.; Arnold, S.L.M.; Riggs, M.W.; Hemphill, A.; Howe, D.K.; Mealey, R.H.; et al. Extended-spectrum antiprotozoal bumped kinase inhibitors: A review. Exp. Parasitol. 2017, 180, 71-83. [CrossRef]

37. Bansal, A.; Ojo, K.K.; Mu, J.; Maly, D.J.; Van Voorhis, W.C.; Miller, L.H. Reduced Activity of Mutant Calcium-Dependent Protein Kinase 1 Is Compensated in Plasmodium falciparum through the Action of Protein Kinase G. mBio 2016, 7. [CrossRef]

38. Lemercier, G.; Fernandez-Montalvan, A.; Shaw, J.P.; Kugelstadt, D.; Bomke, J.; Domostoj, M.; Schwarz, M.K.; Scheer, A.; Kappes, B.; Leroy, D. Identification and characterization of novel small molecules as potent inhibitors of the plasmodial calcium-dependent protein kinase 1. Biochemistry 2009, 48. [CrossRef] [PubMed]

39. Ansell, K.H.; Jones, H.M.; Whalley, D.; Hearn, A.; Taylor, D.L.; Patin, E.C.; Chapman, T.M.; Osborne, S.A.; Wallace, C.; Birchall, K.; et al. Biochemical and antiparasitic properties of inhibitors of the Plasmodium falciparum calcium-dependent protein kinase PfCDPK1. Antimicrob. Agents Chemother. 2014, 58, 6032-6043. [CrossRef] [PubMed]

40. Chapman, T.M.; Osborne, S.A.; Bouloc, N.; Large, J.M.; Wallace, C.; Birchall, K.; Ansell, K.H.; Jones, H.M.; Taylor, D.; Clough, B.; et al. Substituted imidazopyridazines are potent and selective inhibitors of Plasmodium falciparum calcium-dependent protein kinase 1 (PfCDPK1). Bioorg. Med. Chem. Lett. 2013, 23, 3064-3069. [CrossRef]

41. Chapman, T.M.; Osborne, S.A.; Wallace, C.; Birchall, K.; Bouloc, N.; Jones, H.M.; Ansell, K.H.; Taylor, D.L.; Clough, B.; Green, J.L.; et al. Optimization of an imidazopyridazine series of inhibitors of Plasmodium falciparum calcium-dependent protein kinase 1 (PfCDPK1). J. Med. Chem. 2014, 57, 3570-3587. [CrossRef]

42. Large, J.M.; Osborne, S.A.; Smiljanic-Hurley, E.; Ansell, K.H.; Jones, H.M.; Taylor, D.L.; Clough, B.; Green, J.L.; Holder, A.A. Imidazopyridazines as potent inhibitors of Plasmodium falciparum calcium-dependent protein kinase 1 (PfCDPK1): Preparation and evaluation of pyrazole linked analogues. Bioorg. Med. Chem. Lett. 2013, 23, 6019-6024. [CrossRef] [PubMed]

43. Flaherty, B.R.; Ho, T.G.; Schmidt, S.H.; Herberg, F.W.; Peterson, D.S.; Kennedy, E.J. Targeted Inhibition of Plasmodium falciparum Calcium-Dependent Protein Kinase 1 with a Constrained J Domain-Derived Disruptor Peptide. ACS Infect. Dis. 2019, 5, 506-514. [CrossRef]

44. Lima, M.N.N.; Cassiano, G.C.; Tomaz, K.C.P.; Silva, A.C.; Sousa, B.K.P.; Ferreira, L.T.; Tavella, T.A.; Calit, J.; Bargieri, D.Y.; Neves, B.J.; et al. Integrative Multi-Kinase Approach for the Identification of Potent Antiplasmodial Hits. Front. Chem. 2019, 7. [CrossRef]

45. Jain, R.; Gupta, S.; Munde, M.; Pati, S.; Singh, S. Development of novel anti-malarial from structurally diverse library of molecules, targeting plant-like CDPK1, a multistage growth regulator of P. falciparum. Biochem. J. 2020, 477, 1951-1970. [CrossRef] 
46. Cavagnino, A.; Rossi, F.; Rizzi, M. The potent antiplasmodial calmodulin-antagonist trifluoperazine inhibits Plasmodium falciparum calcium-dependent protein kinase 4. Protein Pept. Lett. 2011, 18, 1273-1279. [CrossRef]

47. Huang, W.; Hulverson, M.A.; Zhang, Z.; Choi, R.; Hart, K.J.; Kennedy, M.; Vidadala, R.S.R.; Maly, D.J.; Van Voorhis, W.C.; Lindner, S.E.; et al. 5-Aminopyrazole-4-carboxamide analogues are selective inhibitors of Plasmodium falciparum microgametocyte exflagellation and potential malaria transmission blocking agents. Bioorg. Med. Chem. Lett. 2016, 26, 5487-5491. [CrossRef]

48. Ojo, K.K.; Eastman, R.T.; Vidadala, R.; Zhang, Z.; Rivas, K.L.; Choi, R.; Lutz, J.D.; Reid, M.C.; Fox, A.M.; Hulverson, M.A.; et al. A specific inhibitor of PfCDPK4 blocks malaria transmission: Chemical-genetic validation. J. Infect. Dis. 2014, 209, 275-284. [CrossRef]

49. Ojo, K.K.; Pfander, C.; Mueller, N.R.; Burstroem, C.; Larson, E.T.; Bryan, C.M.; Fox, A.M.; Reid, M.C.; Johnson, S.M.; Murphy, R.C.; et al. Transmission of malaria to mosquitoes blocked by bumped kinase inhibitors. J. Clin. Investig. 2012, 122, 2301-2305. [CrossRef]

50. Vidadala, R.S.; Ojo, K.K.; Johnson, S.M.; Zhang, Z.; Leonard, S.E.; Mitra, A.; Choi, R.; Reid, M.C.; Keyloun, K.R.; Fox, A.M.; et al. Development of potent and selective Plasmodium falciparum calcium-dependent protein kinase 4 (PfCDPK4) inhibitors that block the transmission of malaria to mosquitoes. Eur. J. Med. Chem. 2014, 74, 562-573. [CrossRef]

51. Perrin, M.J.; Subbiah, R.N.; Vandenberg, J.I.; Hill, A.P. Human ether-a-go-go related gene (hERG) K+ channels: Function and dysfunction. Prog. Biophys. Mol. Biol. 2008, 98, 137-148. [CrossRef]

52. Aher, R.B.; Roy, K. Exploring structural requirements for the inhibition of Plasmodium falciparum calciumdependent protein kinase-4 (PfCDPK-4) using multiple in silico approaches. RSC Adv. 2016, 6. [CrossRef]

53. Zhang, Z.; Ojo, K.K.; Vidadala, R.; Huang, W.; Geiger, J.A.; Scheele, S.; Choi, R.; Reid, M.C.; Keyloun, K.R.; Rivas, K.; et al. Potent and selective inhibitors of CDPK1 from T. gondii and C. parvum based on a 5-aminopyrazole-4-carboxamide scaffold. ACS Med. Chem. Lett. 2014, 5, 40-44. [CrossRef]

54. Rout, S.; Mahapatra, R.K. In silico analysis of plasmodium falciparum CDPK5 protein through molecular modeling, docking and dynamics. J. Biol. 2019, 461, 254-267. [CrossRef]

55. Dawn, A.; Singh, S.; More, K.R.; Siddiqui, F.A.; Pachikara, N.; Ramdani, G.; Langsley, G.; Chitnis, C.E. The central role of cAMP in regulating Plasmodium falciparum merozoite invasion of human erythrocytes. PLoS Pathog 2014, 10, e1004520. [CrossRef]

56. Brochet, M.; Collins, M.O.; Smith, T.K.; Thompson, E.; Sebastian, S.; Volkmann, K.; Schwach, F.; Chappell, L.; Gomes, A.R.; Berriman, M.; et al. Phosphoinositide metabolism links cGMP-dependent protein kinase G to essential $\mathrm{Ca}(2)(+)$ signals at key decision points in the life cycle of malaria parasites. PLoS Biol. 2014, 12, e1001806. [CrossRef] [PubMed]

57. Vaid, A.; Sharma, P. PfPKB, a protein kinase B-like enzyme from Plasmodium falciparum: II. Identification of calcium/calmodulin as its upstream activator and dissection of a novel signaling pathway. J. Biol. Chem. 2006, 281. [CrossRef]

58. Wilde, M.; Triglia, T.; Marapana, D.; Thompson, J.K.; Kouzmitchev, A.A.; Bullen, H.E.; Gilson, P.R.; Cowman, A.F.; Tonkin, C.J. Protein kinase A is essential for invasion of Plasmodium falciparum into human erythrocytes. MBio 2019, 10. [CrossRef]

59. Leykauf, K.; Treeck, M.; Gilson, P.R.; Nebl, T.; Braulke, T.; Cowman, A.F.; Gilberger, T.W.; Crabb, B.S. Protein kinase a dependent phosphorylation of apical membrane antigen 1 plays an important role in erythrocyte invasion by the malaria parasite. PLoS Pathog 2010, 6, e1000941. [CrossRef]

60. Patel, A.; Perrin, A.J.; Flynn, H.R.; Bisson, C.; Withers-Martinez, C.; Treeck, M.; Flueck, C.; Nicastro, G.; Martin, S.R.; Ramos, A.; et al. Cyclic AMP signalling controls key components of malaria parasite host cell invasion machinery. PLoS Biol. 2019, 17, e3000264. [CrossRef]

61. Lasonder, E.; Green, J.L.; Camarda, G.; Talabani, H.; Holder, A.A.; Langsley, G.; Alano, P. The Plasmodium falciparum schizont phosphoproteome reveals extensive phosphatidylinositol and cAMP-protein kinase A signaling. J. Proteome Res. 2012, 11. [CrossRef]

62. Merckx, A.; Nivez, M.P.; Bouyer, G.; Alano, P.; Langsley, G.; Deitsch, K.; Thomas, S.; Doerig, C.; Egee, S. Plasmodium falciparum regulatory subunit of cAMP-dependent PKA and anion channel conductance. PLoS Pathog 2008, 4, e40019. [CrossRef] [PubMed]

63. Beraldo, F.H.; Almeida, F.M.; da Silva, A.M.; Garcia, C.R. Cyclic AMP and calcium interplay as second messengers in melatonin-dependent regulation of Plasmodium falciparum cell cycle. J. Cell Biol. 2005, 170, 551-557. [CrossRef] 
64. Falae, A.; Combe, A.; Amaladoss, A.; Carvalho, T.; Menard, R.; Bhanot, P. Role of Plasmodium berghei cGMP-dependent protein kinase in late liver stage development. J. Biol Chem. 2010, 285. [CrossRef]

65. Alam, M.M.; Solyakov, L.; Bottrill, A.R.; Flueck, C.; Siddiqui, F.A.; Singh, S.; Mistry, S.; Viskaduraki, M.; Lee, K.; Hopp, C.S.; et al. Phosphoproteomics reveals malaria parasite Protein Kinase G as a signalling hub regulating egress and invasion. Nat. Commun. 2015, 6. [CrossRef]

66. Collins, C.R.; Hackett, F.; Strath, M.; Penzo, M.; Withers-Martinez, C.; Baker, D.A.; Blackman, M.J. Malaria parasite cGMP-dependent protein kinase regulates blood stage merozoite secretory organelle discharge and egress. PLoS Pathog 2013, 9, e1003344. [CrossRef]

67. Taylor, H.M.; McRobert, L.; Grainger, M.; Sicard, A.; Dluzewski, A.R.; Hopp, C.S.; Holder, A.A.; Baker, D.A. The malaria parasite cyclic GMP-dependent protein kinase plays a central role in blood-stage schizogony. Eukaryot Cell 2010, 9, 37-45. [CrossRef]

68. Vaid, A.; Thomas, D.C.; Sharma, P. Role of Ca2+/calmodulin-PfPKB signaling pathway in erythrocyte invasion by Plasmodium falciparum. J. Biol. Chem. 2008, 283, 5589-5597. [CrossRef]

69. McRobert, L.; Taylor, C.J.; Deng, W.; Fivelman, Q.L.; Cummings, R.M.; Polley, S.D.; Billker, O.; Baker, D.A. Gametogenesis in malaria parasites is mediated by the cGMP-dependent protein kinase. PLoS Biol. 2008, 6, e60139. [CrossRef] [PubMed]

70. Moon, R.W.; Taylor, C.J.; Bex, C.; Schepers, R.; Goulding, D.; Janse, C.J.; Waters, A.P.; Baker, D.A.; Billker, O. A cyclic GMP signalling module that regulates gliding motility in a malaria parasite. PLoS Pathog. 2009, 5, e1000599. [CrossRef]

71. Baker, D.A.; Stewart, L.B.; Large, J.M.; Bowyer, P.W.; Ansell, K.H.; Jimenez-Diaz, M.B.; El Bakkouri, M.; Birchall, K.; Dechering, K.J.; Bouloc, N.S.; et al. A potent series targeting the malarial cGMP-dependent protein kinase clears infection and blocks transmission. Nat. Commun. 2017, 8. [CrossRef]

72. Vanaerschot, M.; Murithi, J.M.; Pasaje, C.F.A.; Ghidelli-Disse, S.; Dwomoh, L.; Bird, M.; Spottiswoode, N.; Mittal, N.; Arendse, L.B.; Owen, E.S.; et al. Inhibition of Resistance-Refractory P. falciparum Kinase PKG Delivers Prophylactic, Blood Stage, and Transmission-Blocking Antiplasmodial Activity. Cell Chem. Biol. 2020, 27. [CrossRef] [PubMed]

73. Penzo, M.; de Las Heras-Duena, L.; Mata-Cantero, L.; Diaz-Hernandez, B.; Vazquez-Muniz, M.J.; Ghidelli-Disse, S.; Drewes, G.; Fernandez-Alvaro, E.; Baker, D.A. High-throughput screening of the Plasmodium falciparum cGMP-dependent protein kinase identified a thiazole scaffold which kills erythrocytic and sexual stage parasites. Sci. Rep. 2019, 9. [CrossRef] [PubMed]

74. Bakkouri, M.; Kouidmi, I.; Wernimont, A.K.; Amani, M.; Hutchinson, A.; Loppnau, P.; Kim, J.J.; Flueck, C.; Walker, J.R.; Seitova, A.; et al. Structures of the cGMP-dependent protein kinase in malaria parasites reveal a unique structural relay mechanism for activation. Proc. Natl. Acad. Sci. USA 2019, 116. [CrossRef]

75. Large, J.M.; Birchall, K.; Bouloc, N.S.; Merritt, A.T.; Smiljanic-Hurley, E.; Tsagris, D.J.; Wheldon, M.C.; Ansell, K.H.; Coombs, P.J.; Kettleborough, C.A.; et al. Potent inhibitors of malarial P. Falciparum protein kinase G: Improving the cell activity of a series of imidazopyridines. Bioorg. Med. Chem. Lett. 2019, 29, 509-514. [CrossRef]

76. Large, J.M.; Birchall, K.; Bouloc, N.S.; Merritt, A.T.; Smiljanic-Hurley, E.; Tsagris, D.J.; Wheldon, M.C.; Ansell, K.H.; Coombs, P.J.; Kettleborough, C.A.; et al. Potent bicyclic inhibitors of malarial cGMP-dependent protein kinase: Approaches to combining improvements in cell potency, selectivity and structural novelty. Bioorg. Med. Chem. Lett. 2019, 29. [CrossRef]

77. Matralis, A.N.; Malik, A.; Penzo, M.; Moreno, I.; Almela, M.J.; Camino, I.; Crespo, B.; Saadeddin, A.; Ghidelli-Disse, S.; Rueda, L.; et al. Development of Chemical Entities Endowed with Potent Fast-Killing Properties against Plasmodium falciparum Malaria Parasites. J. Med. Chem. 2019, 62, 9217-9235. [CrossRef]

78. Tsagris, D.J.; Birchall, K.; Bouloc, N.; Large, J.M.; Merritt, A.; Smiljanic-Hurley, E.; Wheldon, M.; Ansell, K.H.; Kettleborough, C.; Whalley, D.; et al. Trisubstituted thiazoles as potent and selective inhibitors of Plasmodium falciparum protein kinase G (PfPKG). Bioorg. Med. Chem. Lett. 2018, 28, 3168-3173. [CrossRef]

79. Biftu, T.; Feng, D.; Fisher, M.; Liang, G.B.; Qian, X.; Scribner, A.; Dennis, R.; Lee, S.; Liberator, P.A.; Brown, C.; et al. Synthesis and SAR studies of very potent imidazopyridine antiprotozoal agents. Bioorg. Med. Chem. Lett. 2006, 16, 2479-2483. [CrossRef]

80. Biftu, T.; Feng, D.; Ponpipom, M.; Girotra, N.; Liang, G.B.; Qian, X.; Bugianesi, R.; Simeone, J.; Chang, L.; Gurnett, A.; et al. Synthesis and SAR of 2,3-diarylpyrrole inhibitors of parasite cGMP-dependent protein kinase as novel anticoccidial agents. Bioorg. Med. Chem. Lett. 2005, 15. [CrossRef] 
81. Diaz, C.A.; Allocco, J.; Powles, M.A.; Yeung, L.; Donald, R.G.; Anderson, J.W.; Liberator, P.A. Characterization of Plasmodium falciparum cGMP-dependent protein kinase (PfPKG): Antiparasitic activity of a PKG inhibitor. Mol. Biochem. Parasitol. 2006, 146, 78-88. [CrossRef] [PubMed]

82. Mahmood, S.U.; Cheng, H.; Tummalapalli, S.R.; Chakrasali, R.; Yadav Bheemanaboina, R.R.; Kreiss, T.; Chojnowski, A.; Eck, T.; Siekierka, J.J.; Rotella, D.P. Discovery of isoxazolyl-based inhibitors of Plasmodium falciparum cGMP-dependent protein kinase. RSC Med. Chem. 2020, 11, 98-101. [CrossRef]

83. Buskes, M.J.; Harvey, K.L.; Prinz, B.; Crabb, B.S.; Gilson, P.R.; Wilson, D.J.; Abbott, B.M. Exploration of 3-methylisoquinoline-4-carbonitriles as protein kinase A inhibitors of Plasmodium falciparum. Bioorg Med. Chem. 2016, 24, 2389-2396. [CrossRef] [PubMed]

84. Buskes, M.J.; Harvey, K.L.; Richards, B.J.; Kalhor, R.; Christoff, R.M.; Gardhi, C.K.; Littler, D.R.; Cope, E.D.; Prinz, B.; Weiss, G.E.; et al. Antimalarial activity of novel 4-cyano-3-methylisoquinoline inhibitors against Plasmodium falciparum: Design, synthesis and biological evaluation. Org. Biomol. Chem. 2016, 14, 4617-4639. [CrossRef]

85. Kumar, A.; Vaid, A.; Syin, C.; Sharma, P. PfPKB, a novel protein kinase B-like enzyme from Plasmodium falciparum: I. Identification, characterization, and possible role in parasite development. J. Biol. Chem. 2004, 279, 24255-24264. [CrossRef]

86. Littler, D.R.; Bullen, H.E.; Harvey, K.L.; Beddoe, T.; Crabb, B.S.; Rossjohn, J.; Gilson, P.R. Disrupting the Allosteric Interaction between the Plasmodium falciparum cAMP-dependent Kinase and Its Regulatory Subunit. J. Biol. Chem. 2016, 291, 25375-25386. [CrossRef]

87. Sudo, A.; Kato, K.; Kobayashi, K.; Tohya, Y.; Akashi, H. Susceptibility of Plasmodium falciparum cyclic AMP-dependent protein kinase and its mammalian homologue to the inhibitors. Mol. Biochem. Parasitol. 2008, 160, 138-142. [CrossRef]

88. Matthews, H.; Duffy, C.W.; Merrick, C.J. Checks and balances? DNA replication and the cell cycle in Plasmodium. Parasit Vectors 2018, 11. [CrossRef]

89. Doerig, C.; Meijer, L.; Mottram, J.C. Protein kinases as drug targets in parasitic protozoa. Trends Parasitol. 2002, 18, 366-371. [CrossRef]

90. Ross-Macdonald, P.B.; Graeser, R.; Kappes, B.; Franklin, R.; Williamson, D.H. Isolation and expression of a gene specifying a cdc2-like protein kinase from the human malaria parasite Plasmodium falciparum. Eur. J. Biochem. 1994, 220, 693-701. [CrossRef]

91. Holton, S.; Merckx, A.; Burgess, D.; Doerig, C.; Noble, M.; Endicott, J. Structures of P. falciparum PfPK5 test the CDK regulation paradigm and suggest mechanisms of small molecule inhibition. Structure 2003, 11, 1329-1337. [CrossRef]

92. Deshmukh, A.S.; Agarwal, M.; Mehra, P.; Gupta, A.; Gupta, N.; Doerig, C.D.; Dhar, S.K. Regulation of Plasmodium falciparum Origin Recognition Complex subunit 1 (PfORC1) function through phosphorylation mediated by CDK-like kinase PK5. Mol. Microbiol. 2015, 98, 17-33. [CrossRef]

93. Graeser, R.; Wernli, B.; Franklin, R.M.; Kappes, B. Plasmodium falciparum protein kinase 5 and the malarial nuclear division cycles. Mol. Biochem. Parasitol. 1996, 82, 37-49. [CrossRef]

94. Li, J.; Robson, K.J.H.; Chen, J.; Targett, G.A.T.; Baker, D. Pfmrk, a MO15-related protein kinase from Plasmodium falciparum. Eur. J. Biochem. 1996, 241, 805-813. [CrossRef]

95. Jirage, D.; Chen, Y.; Caridha, D.; O’Neil, M.T.; Eyase, F.; Witola, W.H.; Mamoun, C.B.; Waters, N.C. The malarial CDK Pfmrk and its effector PfMAT1 phosphorylate DNA replication proteins and co-localize in the nucleus. Mol. Biochem. Parasitol. 2010, 172, 9-18. [CrossRef]

96. Halbert, J.; Ayong, L.; Equinet, L.; Le Roch, K.; Hardy, M.; Goldring, D.; Reininger, L.; Waters, N.; Chakrabarti, D.; Doerig, C. A Plasmodium falciparum transcriptional cyclin-dependent kinase-related kinase with a crucial role in parasite proliferation associates with histone deacetylase activity. Eukaryot Cell 2010, 9, 952-959. [CrossRef]

97. Doerig, C.; Doerig, C.; Horrocks, P.; Coyle, J.; Carlton, J.; Sultan, A.; Arnot, D.; Carter, R. Pfcrk-1, a developmentally regulated cdc2-related protein kinase of Plasmodium falciparum. Mol. Biochem. Parasitol. 1995, 70, 167-174. [CrossRef]

98. Rangarajan, R.; Bei, A.; Henry, N.; Madamet, M.; Parzy, D.; Nivez, M.P.; Doerig, C.; Sultan, A. Pbcrk-1, the Plasmodium berghei orthologue of P. falciparum cdc-2 related kinase-1 (Pfcrk-1), is essential for completion of the intraerythrocytic asexual cycle. Exp. Parasitol. 2006, 112, 202-207. [CrossRef] 
99. Ganter, M.; Goldberg, J.M.; Dvorin, J.D.; Paulo, J.A.; King, J.G.; Tripathi, A.K.; Paul, A.S.; Yang, J.; Coppens, I.; Jiang, R.H.; et al. Plasmodium falciparum CRK4 directs continuous rounds of DNA replication during schizogony. Nat. Microbiol. 2017, 2. [CrossRef]

100. Bracchi-Ricard, V.; Barik, S.; Delvecchio, C.; Doerig, C.; Chakrabarti, R.; Chakrabarti, D. PfPK6, a novel cyclin-dependent kinase/mitogen-activated protein kinase-related protein kinase from Plasmodium falciparum. Biochem. J. 2000, 347, 255-263. [CrossRef]

101. Dorin-Semblat, D.; Carvalho, T.G.; Nivez, M.-P.; Halbert, J.; Poullet, P.; Semblat, J.-P.; Goldring, D.; Chakrabarti, D.; Mehra, P.; Dhar, S.; et al. An atypical cyclin-dependent kinase controls Plasmodium falciparum proliferation rate. Kinome 2013, 1. [CrossRef]

102. Chen, Y.; Jirage, D.; Caridha, D.; Kathcart, A.K.; Cortes, E.A.; Dennull, R.A.; Geyer, J.A.; Prigge, S.T.; Waters, N.C. Identification of an effector protein and gain-of-function mutants that activate Pfmrk, a malarial cyclin-dependent protein kinase. Mol. Biochem. Parasitol. 2006, 149, 48-57. [CrossRef]

103. Le Roch, K.; Sestier, C.; Dorin, D.; Waters, N.; Kappes, B.; Chakrabarti, D.; Meijer, L.; Doerig, C. Activation of a Plasmodium falciparum cdc2-related kinase by heterologous p25 and cyclin H. J. Biol. Chem. 2000, 275, 8952-8958. [CrossRef]

104. Eubanks, A.L.; Perkins, M.M.; Sylvester, K.; Ganley, J.G.; Posfai, D.; Sanschargrin, P.C.; Hong, J.; Sliz, P.; Derbyshire, E.R. In silico Screening and Evaluation of Plasmodium falciparum Protein Kinase 5 (PK5) Inhibitors. ChemMedChem 2018, 13, 2479-2483. [CrossRef]

105. Xiao, Z.; Waters, N.C.; Woodard, C.L.; Li, Z.; Li, P. Design and synthesis of Pfmrk inhibitors as potential antimalarial agents. Bioorg. Med. Chem. Lett. 2001, 11, 2875-2878. [CrossRef]

106. Woodard, C.L.; Li, Z.; Kathcart, A.K.; Terrell, J.; Gerena, L.; Lopez-Sanchez, M.; Kyle, D.E.; Bhattacharjee, A.K.; Nichols, D.A.; Ellis, W.; et al. Oxindole-based compounds are selective inhibitors of Plasmodium falciparum cyclin dependent protein kinases. J. Med. Chem. 2003, 46, 3877-3882. [CrossRef] [PubMed]

107. Geyer, J.A.; Keenan, S.M.; Woodard, C.L.; Thompson, P.A.; Gerena, L.; Nichols, D.A.; Gutteridge, C.E.; Waters, N.C. Selective inhibition of Pfmrk, a Plasmodium falciparum CDK, by antimalarial 1,3-diaryl-2-propenones. Bioorg. Med. Chem. Lett. 2009, 19, 1982-1985. [CrossRef]

108. Akala, H.M.; Waters, C.N.; Yenesew, A.; Wanjala, C.; Akenga, T.A. In vitro antiplasmodial and cyclin-dependent protein kinase (pfmrk) inhibitory activities of selected flavonoids in combination with chloroquine (CQ) and artemisinin. Res. Pharm. Biotechnol. 2010, 2, 40-50.

109. Bhattacharjee, A.K.; Geyer, J.A.; Woodard, C.L.; Kathcart, A.K.; Nichols, D.A.; Prigge, S.T.; Li, Z.; Mott, B.T.; Waters, N.C. A three-dimensional in silico pharmacophore model for inhibition of Plasmodium falciparum cyclin-dependent kinases and discovery of novel Pfmrk specific inhibitors. J. Med. Chem. 2004, 47, 5418-5426. [CrossRef]

110. Caridha, D.; Kathcart, A.K.; Jirage, D.; Waters, N.C. Activity of substituted thiophene sulfonamides against malarial and mammalian cyclin dependent protein kinases. Bioorg. Med. Chem. Lett. 2010, 20, 3863-3867. [CrossRef]

111. Woodard, C.L.; Keenan, S.M.; Gerena, L.; Welsh, W.J.; Geyer, J.A.; Waters, N.C. Evaluation of broad spectrum protein kinase inhibitors to probe the architecture of the malarial cyclin dependent protein kinase Pfmrk. Bioorg. Med. Chem. Lett. 2007, 17, 4961-4966. [CrossRef] [PubMed]

112. Bhattacharjee, A.K.; Hartell, M.G.; Nichols, D.A.; Hicks, R.P.; Stanton, B.; van Hamont, J.E.; Milhous, W.K. Structure-activity relationship study of antimalarial indolo [2,1-b]quinazoline-6,12-diones (tryptanthrins). Three dimensional pharmacophore modeling and identification of new antimalarial candidates. Eur. J. Med. Chem. 2004, 39, 59-67. [CrossRef] [PubMed]

113. Dominguez, J.N.; Leon, C.; Rodrigues, J.; de Dominguez, N.G.; Gut, J.; Rosenthal, P.J. Synthesis and evaluation of new antimalarial phenylurenyl chalcone derivatives. J. Med. Chem. 2005, 48, 3654-3658. [CrossRef]

114. Go, M.L.; Liu, M.; Wilairat, P.; Rosenthal, P.J.; Saliba, K.J.; Kirk, K. Antiplasmodial chalcones inhibit sorbitol-induced hemolysis of Plasmodium falciparum-infected erythrocytes. Antimicrob. Agents Chemother. 2004, 48, 3241-3245. [CrossRef]

115. Ziegler, H.L.; Hansen, H.S.; Staerk, D.; Christensen, S.B.; Hagerstrand, H.; Jaroszewski, J.W. The antiparasitic compound licochalcone a is a potent echinocytogenic agent that modifies the erythrocyte membrane in the concentration range where antiplasmodial activity is observed. Antimicrob. Agents Chemother. 2004, 48, 4067-4071. [CrossRef] 
116. Joshi, Y.N.; Vinod, P.S.; Yemul, V. Structural annotation and homology modeling of protein kinase 6 (PfPK6) from Plasmodium falciparum. IJSRST 2017, 3, 248-251.

117. Manhani, K.K.; Arcuri, H.A.; da Silveira, N.J.; Uchoa, H.B.; de Azevedo, W.F., Jr.; Canduri, F. Molecular models of protein kinase 6 from Plasmodium falciparum. J. Mol. Model. 2005, 12, 42-48. [CrossRef]

118. Iwanaga, T.; Sugi, T.; Kobayashi, K.; Takemae, H.; Gong, H.; Ishiwa, A.; Murakoshi, F.; Recuenco, F.C.; Horimoto, T.; Akashi, H.; et al. Characterization of Plasmodium falciparum cdc2-related kinase and the effects of a CDK inhibitor on the parasites in erythrocytic schizogony. Parasitol. Int. 2013, 62, 423-430. [CrossRef]

119. Dorin-Semblat, D.; Quashie, N.; Halbert, J.; Sicard, A.; Doerig, C.; Peat, E.; Ranford-Cartwright, L.; Doerig, C. Functional characterization of both MAP kinases of the human malaria parasite Plasmodium falciparum by reverse genetics. Mol. Microbiol. 2007, 65, 1170-1180. [CrossRef]

120. Rangarajan, R.; Bei, A.K.; Jethwaney, D.; Maldonado, P.; Dorin, D.; Sultan, A.A.; Doerig, C. A mitogen-activated protein kinase regulates male gametogenesis and transmission of the malaria parasite Plasmodium berghei. EMBO Rep. 2005, 6, 464-469. [CrossRef]

121. Brumlik, M.J.; Nkhoma, S.; Kious, M.J.; Thompson, G.R., 3rd; Patterson, T.F.; Siekierka, J.J.; Anderson, T.J.; Curiel, T.J. Human p38 mitogen-activated protein kinase inhibitor drugs inhibit Plasmodium falciparum replication. Exp. Parasitol. 2011, 128, 170-175. [CrossRef]

122. Droucheau, E.; Primot, A.; Thomas, V.; Mattei, D.; Knockaert, M.; Richardson, C.; Sallicandro, P.; Alano, P.; Jafarshad, A.; Baratte, B.; et al. Plasmodium falciparum glycogen synthase kinase-3: Molecular model, expression, intracellular localisation and selective inhibitors. Biochim. Biophys. Acta 2004, 1697, 181-196. [CrossRef]

123. Fugel, W.; Oberholzer, A.E.; Gschloessl, B.; Dzikowski, R.; Pressburger, N.; Preu, L.; Pearl, L.H.; Baratte, B.; Ratin, M.; Okun, I.; et al. 3,6-Diamino-4-(2-halophenyl)-2-benzoylthieno[2,3-b]pyridine-5-carbonitriles are selective inhibitors of Plasmodium falciparum glycogen synthase kinase-3. J. Med. Chem. 2013, 56, 264-275. [CrossRef]

124. Kruggel, S.; Lemcke, T. Comparative investigation of the ATP-binding site of human and plasmodial glycogen synthase kinase-3. QSAR Comb. Sci. 2009, 28, 885-890. [CrossRef]

125. Osolodkin, D.I.; Zakharevich, N.V.; Palyulin, V.A.; Danilenko, V.N.; Zefirov, N.S. Bioinformatic analysis of glycogen synthase kinase 3: Human versus parasite kinases. Parasitology 2011, 138, 725-735. [CrossRef]

126. Masch, A.; Nasereddin, A.; Alder, A.; Bird, M.J.; Schweda, S.I.; Preu, L.; Doerig, C.; Dzikowski, R.; Gilberger, T.W.; Kunick, C. Structure-activity relationships in a series of antiplasmodial thieno[2,3-b]pyridines. Malar. J. 2019, 18. [CrossRef]

127. Moolman, C.; Van der Sluis, R.; Beteck, R.M.; Legoabe, L.J. Exploration of benzofuran-based compounds as potent and selective Plasmodium falciparum glycogen synthase kinase-3 (PfGSK-3) inhibitors. 2020, Submitted.

128. Agarwal, S.; Kern, S.; Halbert, J.; Przyborski, J.M.; Baumeister, S.; Dandekar, T.; Doerig, C.; Pradel, G. Two nucleus-localized CDK-like kinases with crucial roles for malaria parasite erythrocytic replication are involved in phosphorylation of splicing factor. J. Cell Biochem. 2011, 112, 1295-1310. [CrossRef]

129. Kern, S.; Agarwal, S.; Huber, K.; Gehring, A.P.; Strodke, B.; Wirth, C.C.; Brugl, T.; Abodo, L.O.; Dandekar, T.; Doerig, C.; et al. Inhibition of the SR protein-phosphorylating CLK kinases of Plasmodium falciparum impairs blood stage replication and malaria transmission. PLoS ONE 2014, 9, e105732. [CrossRef]

130. Talevich, E.; Mirza, A.; Kannan, N. Structural and evolutionary divergence of eukaryotic protein kinases in Apicomplexa. BMC Evol. Biol. 2011, 11, 1-20. [CrossRef] [PubMed]

131. Schneider, M.; Hsiao, H.H.; Will, C.L.; Giet, R.; Urlaub, H.; Luhrmann, R. Human PRP4 kinase is required for stable tri-snRNP association during spliceosomal B complex formation. Nat. Struct. Mol. Biol. 2010, 17, 216-221. [CrossRef]

132. Dixit, A.; Singh, P.K.; Sharma, G.P.; Malhotra, P.; Sharma, P. PfSRPK1, a novel splicing-related kinase from Plasmodium falciparum. J. Biol. Chem. 2010, 285, 38315-38323. [CrossRef]

133. Ngwa, C.J.; Scheuermayer, M.; Mair, G.R.; Kern, S.; Brügl, T.; Wirth, C.C.; Aminake, M.N.; Wiesner, J.; Fischer, R.; Vilcinskas, A.; et al. Changes in the transcriptome of the malaria parasite Plasmodium falciparum during the initial phase of transmission from the human to the mosquito. BMC Genom. 2013, 14, 256. [CrossRef]

134. Eshar, S.; Allemand, E.; Sebag, A.; Glaser, F.; Muchardt, C.; Mandel-Gutfreund, Y.; Karni, R.; Dzikowski, R. A novel Plasmodium falciparum SR protein is an alternative splicing factor required for the parasites' proliferation in human erythrocytes. Nucleic. Acids Res. 2012, 40, 9903-9916. [CrossRef] 
135. Alam, M.M.; Sanchez-Azqueta, A.; Janha, O.; Flannery, E.L.; Mahindra, A.; Mapesa, K.; Char, A.B.; Sriranganadane, D.; Brancucci, N.M.B.; Antonova-Koch, Y.; et al. Validation of the protein kinase PfCLK3 as a multistage cross-species malarial drug target. Science 2019, 365. [CrossRef]

136. Dorin-Semblat, D.; Demarta-Gatsi, C.; Hamelin, R.; Armand, F.; Carvalho, T.G.; Moniatte, M.; Doerig, C. Malaria parasite infected erythrocytes secrete PfCK1, the Plasmodium homologue of the pleiotropic protein kinase casein kinase 1. PLOS ONE 2015, 10, e139591. [CrossRef]

137. Batty, M.B.; Schittenhelm, R.B.; Dorin-Semblat, D.; Doerig, C.; Garcia-Bustos, J.F. Interaction of Plasmodium falciparum casein kinase 1 with components of host cell protein trafficking machinery. IUBMB Life 2020. [CrossRef] [PubMed]

138. Reininger, L.; Wilkes, J.M.; Bourgade, H.; Miranda-Saavedra, D.; Doerig, C. An essential Aurora-related kinase transiently associates with spindle pole bodies during Plasmodium falciparum erythrocytic schizogony. Mol. Microbiol. 2011, 79, 205-221. [CrossRef]

139. Carvalho, T.G.; Doerig, C.; Reininger, L. Nima- and Aurora-related kinases of malaria parasites. Biochim. Biophys. Acta 2013, 1834, 1336-1345. [CrossRef]

140. Desoubzdanne, D.; Marcourt, L.; Raux, R.; Chevalley, S.; Dorin, D.; Doerig, C.; Valentin, A.; Ausseil, F.; Debitus, C. Alisiaquinones and alisiaquinol, dual inhibitors of Plasmodium falciparum enzyme targets from a new caledonian deep water sponge. J. Nat. Prod. 2008, 71, 1189-1192. [CrossRef]

141. Laurent, D.; Jullian, V.; Parenty, A.; Knibiehler, M.; Dorin, D.; Schmitt, S.; Lozach, O.; Lebouvier, N.; Frostin, M.; Alby, F.; et al. Antimalarial potential of xestoquinone, a protein kinase inhibitor isolated from a Vanuatu marine sponge Xestospongia sp. Bioorg. Med. Chem. 2006, 14, 4477-4482. [CrossRef]

142. Lebouvier, N.; Jullian, V.; Desvignes, I.; Maurel, S.; Parenty, A.; Dorin-Semblat, D.; Doerig, C.; Sauvain, M.; Laurent, D. Antiplasmodial activities of homogentisic acid derivative protein kinase inhibitors isolated from a Vanuatu marine sponge Pseudoceratina sp. Mar. Drugs 2009, 7, 640-653. [CrossRef]

143. Patel, G.; Roncal, N.E.; Lee, P.J.; Leed, S.E.; Erath, J.; Rodriguez, A.; Sciotti, R.J.; Pollastri, M.P. Repurposing human Aurora kinase inhibitors as leads for anti-protozoan drug discovery. Medchemcomm 2014, 5, 655-658. [CrossRef]

144. Brown, J.R.; Auger, K.R. Phylogenomics of phosphoinositide lipid kinases: Perspectives on the evolution of second messenger signalling and drug discovery. BMC Evol. Biol. 2011, 11, 4. [CrossRef]

145. McNamara, C.W.; Lee, M.C.; Lim, C.S.; Lim, S.H.; Roland, J.; Simon, O.; Yeung, B.K.; Chatterjee, A.K.; McCormack, S.L.; Manary, M.J.; et al. Targeting Plasmodium PI(4)K to eliminate malaria. Nature 2013, 504, 248-253. [CrossRef]

146. Tawk, L.; Chicanne, G.; Dubremetz, J.F.; Richard, V.; Payrastre, B.; Vial, H.J.; Roy, C.; Wengelnik, K. Phosphatidylinositol 3-phosphate, an essential lipid in Plasmodium, localizes to the food vacuole membrane and the apicoplast. Eukaryot Cell 2010, 9, 1519-1530. [CrossRef]

147. Vaid, A.; Ranjan, R.; Smythe, W.A.; Hoppe, H.C.; Sharma, P. PfPI3K, a phosphatidylinositol-3 kinase from Plasmodium falciparum, is exported to the host erythrocyte and is involved in hemoglobin trafficking. Blood 2010, 115, 2500-2507. [CrossRef]

148. Mbengue, A.; Bhattacharjee, S.; Pandharkar, T.; Liu, H.; Estiu, G.; Stahelin, R.V.; Rizk, S.S.; Njimoh, D.L.; Ryan, Y.; Chotivanich, K.; et al. A molecular mechanism of artemisinin resistance in Plasmodium falciparum malaria. Nature 2015, 520, 683-687. [CrossRef]

149. Ibrahim, M.A.A.; Abdelrahman, A.H.M.; Hassan, A.M.A. Identification of novel Plasmodium falciparum PI4KB inhibitors as potential anti-malarial drugs: Homology modeling, molecular docking and molecular dynamics simulations. Comput. Biol. Chem. 2019, 80, 79-89. [CrossRef]

150. Le Manach, C.; Gonzalez Cabrera, D.; Douelle, F.; Nchinda, A.T.; Younis, Y.; Taylor, D.; Wiesner, L.; White, K.L.; Ryan, E.; March, C.; et al. Medicinal chemistry optimization of antiplasmodial imidazopyridazine hits from high throughput screening of a SoftFocus kinase library: Part 1. J. Med. Chem. 2014, 57, 2789-2798. [CrossRef]

151. Le Manach, C.; Paquet, T.; Gonzalez Cabrera, D.; Younis, Y.; Taylor, D.; Wiesner, L.; Lawrence, N.; Schwager, S.; Waterson, D.; Witty, M.J.; et al. Medicinal chemistry optimization of antiplasmodial imidazopyridazine hits from high throughput screening of a softfocus kinase library: Part 2. J. Med. Chem. 2014, 57, 8839-8848. [CrossRef]

152. Zou, B.; Nagle, A.; Chatterjee, A.K.; Leong, S.Y.; Tan, L.J.; Sim, W.L.; Mishra, P.; Guntapalli, P.; Tully, D.C.; Lakshminarayana, S.B.; et al. Lead optimization of imidazopyrazines: A new class of antimalarial with activity on Plasmodium liver stages. ACS Med. Chem. Lett. 2014, 5, 947-950. [CrossRef] 
153. Gibhard, L.; Njoroge, M.; Paquet, T.; Brunschwig, C.; Taylor, D.; Lawrence, N.; Abay, E.; Wittlin, S.; Wiesner, L.; Street, L.J.; et al. Investigating Sulfoxide-to-Sulfone Conversion as a Prodrug Strategy for a Phosphatidylinositol 4-Kinase Inhibitor in a Humanized Mouse Model of Malaria. Antimicrob. Agents Chemother. 2018, 62. [CrossRef] [PubMed]

154. Le Manach, C.; Nchinda, A.T.; Paquet, T.; Gonzalez Cabrera, D.; Younis, Y.; Han, Z.; Bashyam, S.; Zabiulla, M.; Taylor, D.; Lawrence, N.; et al. Identification of a Potential Antimalarial Drug Candidate from a Series of 2-Aminopyrazines by Optimization of Aqueous Solubility and Potency across the Parasite Life Cycle. J. Med. Chem. 2016, 59, 9890-9905. [CrossRef]

155. Younis, Y.; Douelle, F.; Feng, T.S.; Gonzalez Cabrera, D.; Le Manach, C.; Nchinda, A.T.; Duffy, S.; White, K.L.; Shackleford, D.M.; Morizzi, J.; et al. 3,5-Diaryl-2-aminopyridines as a novel class of orally active antimalarials demonstrating single dose cure in mice and clinical candidate potential. J. Med. Chem. 2012, 55, 3479-3487. [CrossRef]

156. Younis, Y.; Douelle, F.; Gonzalez Cabrera, D.; Le Manach, C.; Nchinda, A.T.; Paquet, T.; Street, L.J.; White, K.L.; Zabiulla, K.M.; Joseph, J.T.; et al. Structure-activity-relationship studies around the 2-amino group and pyridine core of antimalarial 3,5-diarylaminopyridines lead to a novel series of pyrazine analogues with oral in vivo activity. J. Med. Chem. 2013, 56, 8860-8871. [CrossRef]

157. Liang, X.; Jiang, Z.; Huang, Z.; Li, F.; Chen, C.; Hu, C.; Wang, W.; Hu, Z.; Liu, Q.; Wang, B.; et al. Discovery of 6'-chloro-N-methyl-5' -(phenylsulfonamido)-[3,3'-bipyridine]-5-carboxamide (CHMFL-PI4K-127) as a novel Plasmodium falciparum $\mathrm{PI}(4) \mathrm{K}$ inhibitor with potent antimalarial activity against both blood and liver stages of Plasmodium. Eur. J. Med. Chem. 2020, 188. [CrossRef]

158. Paquet, T.; Le Manach, C.; Cabrera, D.G.; Younis, Y.; Henrich, P.P.; Abraham, T.S.; Lee, M.C.S.; Basak, R.; Ghidelli-Disse, S.; Lafuente-Monasterio, M.J.; et al. Antimalarial efficacy of MMV390048, an inhibitor of Plasmodium phosphatidylinositol 4-kinase. Sci. Transl. Med. 2017, 9, eaad9735. [CrossRef]

159. Sinxadi, P.; Donini, C.; Johnstone, H.; Langdon, G.; Wiesner, L.; Allen, E.; Duparc, S.; Chalon, S.; McCarthy, J.S.; Lorch, U.; et al. Safety, tolerability, pharmacokinetics, and antimalarial activity of the novel Plasmodium phosphatidylinositol 4-kinase inhibitor MMV390048 in healthy volunteers. Antimicrob. Agents Chemother. 2020, 64. [CrossRef]

160. Brunschwig, C.; Lawrence, N.; Taylor, D.; Abay, E.; Njoroge, M.; Basarab, G.S.; Le Manach, C.; Paquet, T.; Cabrera, D.G.; Nchinda, A.T.; et al. UCT943, a next-generation Plasmodium falciparum PI4K inhibitor preclinical candidate for the treatment of malaria. Antimicrob. Agents Chemother. 2018, 62. [CrossRef]

161. Chaudhary, K.K.; Gupta, S.K.; Mishra, N. An In Silico Approach for Targeting Plasmodium Phosphatidylinositol 4-Kinase to Eradicate Malaria. In Advanced Computing and Communication Technologies; Springer: Singapore, 2016; pp. 279-287. [CrossRef]

162. Ren, J.X.; Gao, N.N.; Cao, X.S.; Hu, Q.A.; Xie, Y. Homology modeling and virtual screening for inhibitors of lipid kinase PI(4)K from Plasmodium. Biomed. Pharm. 2016, 83, 798-808. [CrossRef]

163. Lucet, I.S.; Tobin, A.; Drewry, D.; Wilks, A.F.; Doerig, C. Plasmodium kinases as targets for new-generation antimalarials. Future Med. Chem. 2012, 4, 2295-2310. [CrossRef]

164. Dorin, D.; Semblat, J.P.; Poullet, P.; Alano, P.; Goldring, J.P.; Whittle, C.; Patterson, S.; Chakrabarti, D.; Doerig, C. PfPK7, an atypical MEK-related protein kinase, reflects the absence of classical three-component MAPK pathways in the human malaria parasite Plasmodium falciparum. Mol. Microbiol. 2005, 55, 184-196. [CrossRef]

165. Dorin-Semblat, D.; Sicard, A.; Doerig, C.; Ranford-Cartwright, L.; Doerig, C. Disruption of the PfPK7 gene impairs schizogony and sporogony in the human malaria parasite Plasmodium falciparum. Eukaryot Cell 2008, 7, 279-285. [CrossRef]

166. Zhang, M.; Wang, C.; Otto, T.D.; Oberstaller, J.; Liao, X.; Adapa, S.R.; Udenze, K.; Bronner, I.F.; Casandra, D.; Mayho, M.; et al. Uncovering the essential genes of the human malaria parasite Plasmodium falciparum by saturation mutagenesis. Science 2018, 360. [CrossRef] [PubMed]

167. Philip, N.; Haystead, T.A. Characterization of a UBC13 kinase in Plasmodium falciparum. Proc. Natl. Acad. Sci. USA 2007, 104, 7845-7850. [CrossRef]

168. Schneider, A.G.; Mercereau-Puijalon, O. A new Apicomplexa-specific protein kinase family: Multiple members in Plasmodium falciparum, all with an export signature. BMC Genom. 2005, 6. [CrossRef] 
169. Nunes, M.C.; Goldring, J.P.; Doerig, C.; Scherf, A. A novel protein kinase family in Plasmodium falciparum is differentially transcribed and secreted to various cellular compartments of the host cell. Mol. Microbiol. 2007, 63, 391-403. [CrossRef]

170. Nunes, M.C.; Okada, M.; Scheidig-Benatar, C.; Cooke, B.M.; Scherf, A. Plasmodium falciparum FIKK kinase members target distinct components of the erythrocyte membrane. PLoS ONE 2010, 5, e11747. [CrossRef]

171. Siddiqui, G.; Proellochs, N.I.; Cooke, B.M. Identification of essential exported Plasmodium falciparum protein kinases in malaria-infected red blood cells. Br. J. Haematol. 2020, 188, 774-783. [CrossRef]

172. Kats, L.M.; Fernandez, K.M.; Glenister, F.K.; Herrmann, S.; Buckingham, D.W.; Siddiqui, G.; Sharma, L.; Bamert, R.; Lucet, I.; Guillotte, M.; et al. An exported kinase (FIKK42) that mediates virulence-associated changes in Plasmodium falciparum-infected red blood cells. Int. J. Parasitol. 2014, 44, 319-328. [CrossRef]

173. Brandt, G.S.; Bailey, S. Dematin, a human erythrocyte cytoskeletal protein, is a substrate for a recombinant FIKK kinase from Plasmodium falciparum. Mol. Biochem. Parasitol. 2013, 191, 20-23. [CrossRef]

174. Merckx, A.; Echalier, A.; Langford, K.; Sicard, A.; Langsley, G.; Joore, J.; Doerig, C.; Noble, M.; Endicott, J. Structures of P. falciparum protein kinase 7 identify an activation motif and leads for inhibitor design. Structure 2008, 16, 228-238. [CrossRef]

175. Bouloc, N.; Large, J.M.; Smiljanic, E.; Whalley, D.; Ansell, K.H.; Edlin, C.D.; Bryans, J.S. Synthesis and in vitro evaluation of imidazopyridazines as novel inhibitors of the malarial kinase PfPK7. Bioorg. Med. Chem. Lett. 2008, 18, 5294-5298. [CrossRef] [PubMed]

176. Klein, M.; Diner, P.; Dorin-Semblat, D.; Doerig, C.; Grotli, M. Synthesis of 3-(1,2,3-triazol-1-yl)- and 3-(1,2,3-triazol-4-yl)-substituted pyrazolo[3,4-d]pyrimidin-4-amines via click chemistry: Potential inhibitors of the Plasmodium falciparum PfPK7 protein kinase. Org. Biomol. Chem. 2009, 7, 3421-3429. [CrossRef]

177. Raphemot, R.; Eubanks, A.L.; Toro-Moreno, M.; Geiger, R.A.; Hughes, P.F.; Lu, K.Y.; Haystead, T.A.J.; Derbyshire, E.R. Plasmodium PK9 Inhibitors Promote Growth of Liver-Stage Parasites. Cell Chem. Biol. 2019, 26. [CrossRef] [PubMed]

178. Totzke, J.; Gurbani, D.; Raphemot, R.; Hughes, P.F.; Bodoor, K.; Carlson, D.A.; Loiselle, D.R.; Bera, A.K.; Eibschutz, L.S.; Perkins, M.M.; et al. Takinib, a Selective TAK1 Inhibitor, Broadens the Therapeutic Efficacy of TNF-alpha Inhibition for Cancer and Autoimmune Disease. Cell Chem. Biol. 2017, 24. [CrossRef]

179. Hodge, C.D.; Spyracopoulos, L.; Glover, J.N.M. Ubc13: The Lys63 ubiquitin chain building machine. Oncotarget 2016, 7, 64471-64504. [CrossRef]

180. Tewari, R.; Straschil, U.; Bateman, A.; Bohme, U.; Cherevach, I.; Gong, P.; Pain, A.; Billker, O. The systematic functional analysis of Plasmodium protein kinases identifies essential regulators of mosquito transmission. Cell Host Microbe 2010, 8, 377-387. [CrossRef]

181. Osman, K.T.; Lou, H.J.; Qiu, W.; Brand, V.; Edwards, A.M.; Turk, B.E.; Hui, R. Biochemical characterization of FIKK8-A unique protein kinase from the malaria parasite Plasmodium falciparum and other apicomplexans. Mol. Biochem. Parasitol. 2015, 201, 85-89. [CrossRef]

182. Lin, B.C.; Harris, D.R.; Kirkman, L.M.D.; Perez, A.M.; Qian, Y.; Schermerhorn, J.T.; Hong, M.Y.; Winston, D.S.; Xu, L.; Brandt, G.S. FIKK Kinase, a Ser/Thr Kinase Important to Malaria Parasites, Is Inhibited by Tyrosine Kinase Inhibitors. ACS Omega 2017, 2, 6605-6612. [CrossRef]

183. Knight, Z.A.; Shokat, K.M. Features of selective kinase inhibitors. Chem. Biol. 2005, 12, 621-637. [CrossRef]

184. Lin, B.C.; Harris, D.R.; Kirkman, L.M.D.; Perez, A.M.; Qian, Y.; Schermerhorn, J.T.; Hong, M.Y.; Winston, D.S.; Xu, L.; Lieber, A.M.; et al. The anthraquinone emodin inhibits the non-exported FIKK kinase from Plasmodium falciparum. Bioorg. Chem. 2017, 75, 217-223. [CrossRef]

185. Yuan, J.; Johnson, R.L.; Huang, R.; Wichterman, J.; Jiang, H.; Hayton, K.; Fidock, D.A.; Wellems, T.E.; Inglese, J.; Austin, C.P.; et al. Genetic mapping of targets mediating differential chemical phenotypes in Plasmodium falciparum. Nat. Chem. Biol. 2009, 5, 765-771. [CrossRef]

Publisher's Note: MDPI stays neutral with regard to jurisdictional claims in published maps and institutional affiliations. 